University of New Hampshire

University of New Hampshire Scholars' Repository

$5-1-1975$

\title{
Environmental Requirements of Selected Estuarine Ciliated Protozoa
}

Arthur C. Borror

University of New Hampshire

Follow this and additional works at: https://scholars.unh.edu/jel

\section{Recommended Citation}

Borror, A.C. 1975. Environmental Requirements of Selected Estuarine Ciliated Protozoa. National Environmental Research Center Office of Research and Development, US Environmental Protection Agency, Corvallis, OR. v + 49 pp.

This Article is brought to you for free and open access by the Institute for the Study of Earth, Oceans, and Space (EOS) at University of New Hampshire Scholars' Repository. It has been accepted for inclusion in Jackson Estuarine Laboratory by an authorized administrator of University of New Hampshire Scholars' Repository. For more information, please contact Scholarly.Communication@unh.edu. 
EPA-660/3-74-031

MAY 1975

Ecological Research Series

\section{Environmental Requirements of Selected Estuarine Ciliated Protozoa}

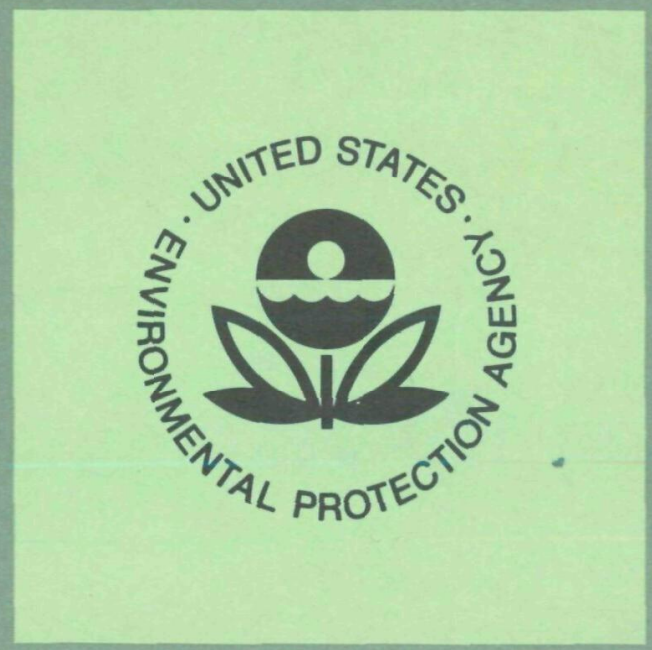

National Environmental Research Center Office of Research and Development U.S. Environmental Protection Agency 


\section{RESEARCH REPORTING SERIES}

Research reports of the Office of Research and Development, U.S. Environmental Protection Agency, have been grouped into five series. These five broad categories were established to facilitate further development and application of environmental technology. Elimination of traditional grouping was consciousiy planned to foster technology transfer and a maximum interface in related fields. The five series are:

1. Environmental Health Effects Research

2. Environmental Protection Technology

3. Ecological Research

4. Environmental Monitoring

5. Socioeconomic Environmental Studies

This report has been assigned to the ECOLOGICAL RESEARCH STUDIES series. This series describes research on the effects of pollution on humans, plant and animal species, and materials. Problems are assessed for their long- and short-term influences. Investigations include formation, transport, and pathway studies to determine the fate of pollutants and their effects. This work provides the technical basis for setting standards to minimize undesirable changes in living organisms in the aquatic, terrestrial and atmospheric environments.

\section{EPA REVIEW NOTICE}

This report has been reviewed by the Office of Research and Development, EPA, and approved for publication. Approval does not signify that the contents necessarily reflect the views and policies of the Environmental Protection Agency, nor does mention of trade names or commercial products constitute endorsement or recommendation for use. 
ENVIRONMENTAL REQUIREMENTS OF SELECTED

ESTUARINE CILIATED PROTOZOA

by

Arthur C. Borror

Department of Zoology

University of New Hampshire

Durham, New Hampshire

Grant No. 18080 FBW

Program Element 1BA022

Project Officer

Juan G. Gonzalez

National Marine Water Quality Laboratory

National Environmental Research Center

South Ferry Road

Narragansett, Rhode Island 02882

NATIONAL ENVIRONMENTAL RESEARCH CENTER OFFICE OF RESEARCH AND DEVELOPMENT

U. S. ENVIRONMENTAL PROTECTION AGENCY

CORVALLIS, OREGON 97330 Fof Sale by the National Technical Information Service
U.S. Department of Commerce, Springfield, VA 22151 


\section{ABSTRACT}

This report addresses species composition and microdistribution of ciliates (Protozoa, Ciliophora) of a tidal marsh at Adams Pt., Great Bay, New Hampshire $(1970,1971)$ in relationship to temperature, salinity, $\mathrm{pH}$, concentration of oxygen, $\mathrm{H}_{2} \mathrm{~S}$, and bacteria, and occurrence of micrometazoa. Accurate counting and precise identification allowed measurement of tidal effects on ciliate abundance and diversity, and the relationship of ciliates to micrometazoa and bacteria.

During 1970, we identified 79 species in 175 collections; during 1971, 83 species in 102 collections. Although in general ciliate distribution was not correlated with temperature, salinity, $\mathrm{pH}$, or oxygen concentration, some species were tolerant of anoxic environments. Ciliates differed in distribution between the upper (Spartina patens) and the lower (S.alterniflora) marsh. We measured responses of bacteria and ciliates to the physical and biological changes in a patens-panne pond caused by tidal flushing, and to the flushing of a channel in the lower marsh by several different tidal cycles.

This report was submitted in fulfillment of Grant 18080 FBW by The University of New Hampshire, Durham, under the sponsorship of the Environmental Protection Agency. Work was completed as of September 1971. 
CONTENTS

$\underline{\text { Page }}$

Abstract

ii

List of Tables

Acknowledgements

vi

Sections

I Conclusions

1

II Recomendations 3

III Introduction 4

IV Materials and Methods 9

$\begin{array}{lll}V & \text { Experimental Phase } & 15\end{array}$

VI Discussion 41

VII References $\quad 44$

VIII List of Publications 49 
TABLES

№.

Page

1 Occurrence of several species as a function of salinity 21

2 Coleps tesselatus occurrence and abundance as a function of oxygen concentration

3 Mesodinium pulex occurrence and abundance as a function of oxygen concentration

4 Uronema filificum occurrence and abundance as a function of oxygen concentration

5 Strombidium sulcatum occurrence and abundance as a function of oxygen concentration

6 Strombidium styliferum occurrence and abundance as a function of oxygen concentration

7 Strombidium latum occurrence and abundance as a function of oxygen concentration

8 Faunal differences between upper and lower marsh

9 Locomotory types represented by species unique to either upper marsh or lower marsh

10 Faunal differences between upper and lower marsh

11 Physical and biological parameters of a patens-panne pond 32

12 Physical and biological parameters in the lower marsh during a full moon spring tide cycle

13 Physical and biological parameters in the lower marsh during a neap tide cycle

14 Physical and biological parameters in the lower marsh during a new moon spring tide cycle 


\section{ACKNOWLEDGEMENTS}

The valuable assistance of Miss Hope Godino, Mr. Kenneth McGeary, and Mr. Edward Washburn, Research Assistants, is gratefully acknowledged.

Additionally, the productive input of Mr. Richard Kool, Mr. and Mrs. Gerry Gagne, and Mrs. Edward Washburn, Laboratory Assistants, is also greatly appreciated. 
SECTION I

CONCLUSIONS

During 1970 and 1971, 103 species of ciliates, representing 41 families and 10 orders were identified.

No correlations were noted between ciliate occurrence or abundance and the factor of temperature.

Several instances of negative correlations between ciliate concentration and $\mathrm{H}_{2} \mathrm{~S}$ concentration were observed.

Although some pairs of closely related species showed differences in relationship to salinity, occurrence of the most frequently encountered species showed no correlation with salinity.

In general the most regularly occurring species show no obvious correlation either in occurrence or abundance with oxygen concentration. However, numerous less regularly occurring species are tolerant of anoxic environments.

Taxonomic procedures allowing precise species identification permitted assessment of critical differences in microdistribution. Comparison of ciliate faunas of the upper and lower marsh indicates instances of intrageneric differences in distribution.

Tidal flushing of pools in the patens-panne upper marsh apparently cause no effects upon bacterial numbers. Following flushing of such ponds by high water, there appeared an increase in ciliate diversity on the bottom, and a pulse in ciliate concentration. At such times, Coleps tesselatus, that occurred more regularly in the upper marsh than in the lower marsh, apparently was flushed through the channels of the lower marsh and appeared in greater than usual concentration on the bottom of the tidal channels.

Ciliates on the bottom of tidal channels of the lower marsh occurred at greater concentrations and in greater variety at ebb tide than at flood tide. By contrast, ciliates in surface waters of tidal channels of the lower marsh occurred at greatest concentrations at flood tide, reflecting an influx of individuals from the estuary.

There was no significant correlation between numbers of ciliates and bacterial concentration in tidal channels of the lower marsh during the course of a tidal cycle, whether it was a full moon spring tide, new moon spring tide, or neap tide. 
Tidal marsh ciliates appear to settle into the detritus in the bottom of the tidal channels of the lower marsh following flooding of the marsh by a tidal cycle. In general they are not flushed out onto the mud of the estuary below the marsh.

Contribution of tidal marsh ciliates in general to estuarine food webs probably occurs through their association with particulate detritus.

Tidal marsh ciliates do not seem to play a significant role in the transfer of organic matter from tidal marshes to the rest of the estuary except insofar as they are carried from the marsh on particulate organic detritus. Likewise, their concentrations in tidal marshes are not

noticeably increased by influx of protozoa from the estuary during flood tide. 
Because of intrageneric differences in responses of ciliates to environmental factors careful species identification is necessary in any application of differences in ciliate microdistribution to assessment of biological effects of changing water quality.

Direct counts of living protozoa augmented by permanent cytological preparations are practical, consistent, and allow qualitative and quantitative assessment of responses of ciliate populations to changes in water quality.

Estimation of bacterial standing crop by Most Probable Number methods was inadequate for assessment of the correlation between changes in ciliate populations and changes in bacterial concentration, thus should be replaced in future work by alternative approaches to measuring bacterial density, such as direct observation counts.

Data such as those provided in this report can act as a baseline for comparing protozoan diversity among marine habitats. These data indicate a possible source of information for assessing biological response to changing chemical and physical parameters in estuaries. Comparison of the character of the ciliate fauna of tidal marshes subject to water of differing quality should provide further understanding of the response of tidal marshes to possible factors associated with pollution. 
SECTION III

INTRODUCTION

This study is designed to determine the possible role of ciliated microorganisms (Phylum Protozoa, class Ciliophora) as water pollution indicators. It involves investigation of factors affecting species composition and microdistribution of populations of intertidal ciliates of the tidal marshes of the Great Bay - Little Bay estuary, New Hampshire, where they reach particularly high population densities. The relationship of ciliates to the rest of the decomposer food chain and their role in the tidal marsh and estuarine productivity will be investigated. Measurements of relative and absolute abundance of members of the microbenthos, correlated with variations of physical, chemical, and microbiological tactors, will be employed in assessing diurnal and monthly changes in ciliate community structure. The research was carried out using facilities at the University of New Hampshire, and the Jackson Estuarine Laboratory of the University of New Hampshire, on Adams Pt., Great Bay, New Hampshire.

The necessity of a fuller understanding of the biological complexity of the estuaries of the northeastern coast of the United States is becoming greater with the increasing stress put on these systems by our increasing population and its technology ${ }^{l}$. As a site of a significant if not major portion of the productivity of estuaries, tidal marshes in particular continue to be important foci for basic research 2,3 . Evidence from many directions implicates bacterial decomposition of detritus derived from tidal marshes as one of the basic processes of energy transformation involved in the food chains of estuaries ${ }^{4-9}$.

In addition, primary productivity by microscopic saltmarsh algae provides a significant fraction of the carbon available for estuarine ecosystems ${ }^{10-12}$. During the past 10 years, the approximately 50 publications on taxonomy, distribution, and ecology of free-living benthic ciliated protozoa continues to demonstrate that ciliates are cosmopolitan, their local occurrence depending on suitable microhabitats. A large number of these papers report investigations of the psammolittoral zone, with emphasis on physical factors (e.g. that of Dragesco ${ }^{13}$ ). There have been few investigations of ciliates of tidal marshes, compared with the psammolittoral zone14,15. Despite the known high productivity of tidal marshes, and the potential these coastal wetlands have for supporting a rich and diverse microfauna, relatively few protozoologists have investigated the ditches, pools, and algal mats of coastal marshes. Compared with the ciliate fauna of other marine habitats, such as the psammolittoral, little is known of the extent or variety of the ciliate population inhabiting coastal wetlands. 
By contrast, numerous protozoologists have come to the conclusion that in fresh water habitats, ciliates occur in a wide variety of habitats and may have value in assessing water quality 16-20.

While conducting doctoral research on ecological relationships among benthic marine ciliates at the Florida state University ${ }^{21}$ it became increasingly clear to me that patterns of distribution of marine ciliates were correlated with availability of suitable microhabitats ${ }^{22}$. Some of this dependence was related to food and feeding; studies of Cohnilembus indicated morphological specializations associated with feeding and locomotory behavior ${ }^{23}$. After moving to the University of New Hampshire, my interests in morphological specialization of ciliates and their relationships to ecology continued ${ }^{24}$. Studies of distribution of ciliates 25 further indicated that congenors occupied different niches and often different microhabitats.

Effects of levels of viral and bacterial pollution upon shellfish production and productivity in the Great Bay - Little Bay estuarine complex are continuing areas of investigation at the University of New Hampshire. However, the ciliated protozoa, members of the next higher trophic level to bacteria in the decomposer food chain, had been investigated here only preliminarily. Thus I began investigation of the morphology and ecology of tidal marsh ciliates 26,27 . A series of monthly samples between July, 1964 and June, 1965 showed seasonal differences in population structure, replacement of species, and indications of differences in ciliate fauna compared with intertidal mud or sand. These studies and others ${ }^{28-33}$ suggested that ciliates play an important role in the ecology of the benthos and show responses to factors that may allow them to be useful as indicator organisms. The ciliated protozoa in addition seem particularly adaptable to investigation of ecological principles at work $34-38$.

\section{THEORETICAL APPROACHES}

This study has been planned to include taxonomic procedures to assure precise species identification and an approach to ciliate community ecology to allow assessment of seasonal turnover and succession. Critical differences in microdistribution may be significant in relationship to spatial differences in environmental factors associated with pollution. This is expected to be a relatively unique and significant aspect of the research and is necessary prior to evaluation of particular species as indicator organisms. 


\section{Faunistic study}

Despite our information generally on the biology of Great Bay ${ }^{39}$, and the wealth of information on the microbiology of the Bay 40,41 , the ecological role of ciliates here has been little studied. Published works from elsewhere in the world suggest that one should expect to find rich and diverse ciliate faunas in appropriate microhabitats in Great Bay $42-46$. The following faunistic study enables one to identify possible competitive situations, to assess the relationship of locomotory type with microhabitat preference, allows assessment of possible correlation of microdistribution with various physical and chemical factors, and finally allows enumeration of species available for further culturing and experimental purposes.

\section{Quantitative Sampling}

Development of accurate and reproducible counting methods for tidal marsh ciliates should allow assessment of effects of tidal flushing upon ciliate abundance and diversity, tide cycle effects upon contribution of ciliates to the estuary proper, and the relationship of ciliates to micrometazoa and bacteria. 


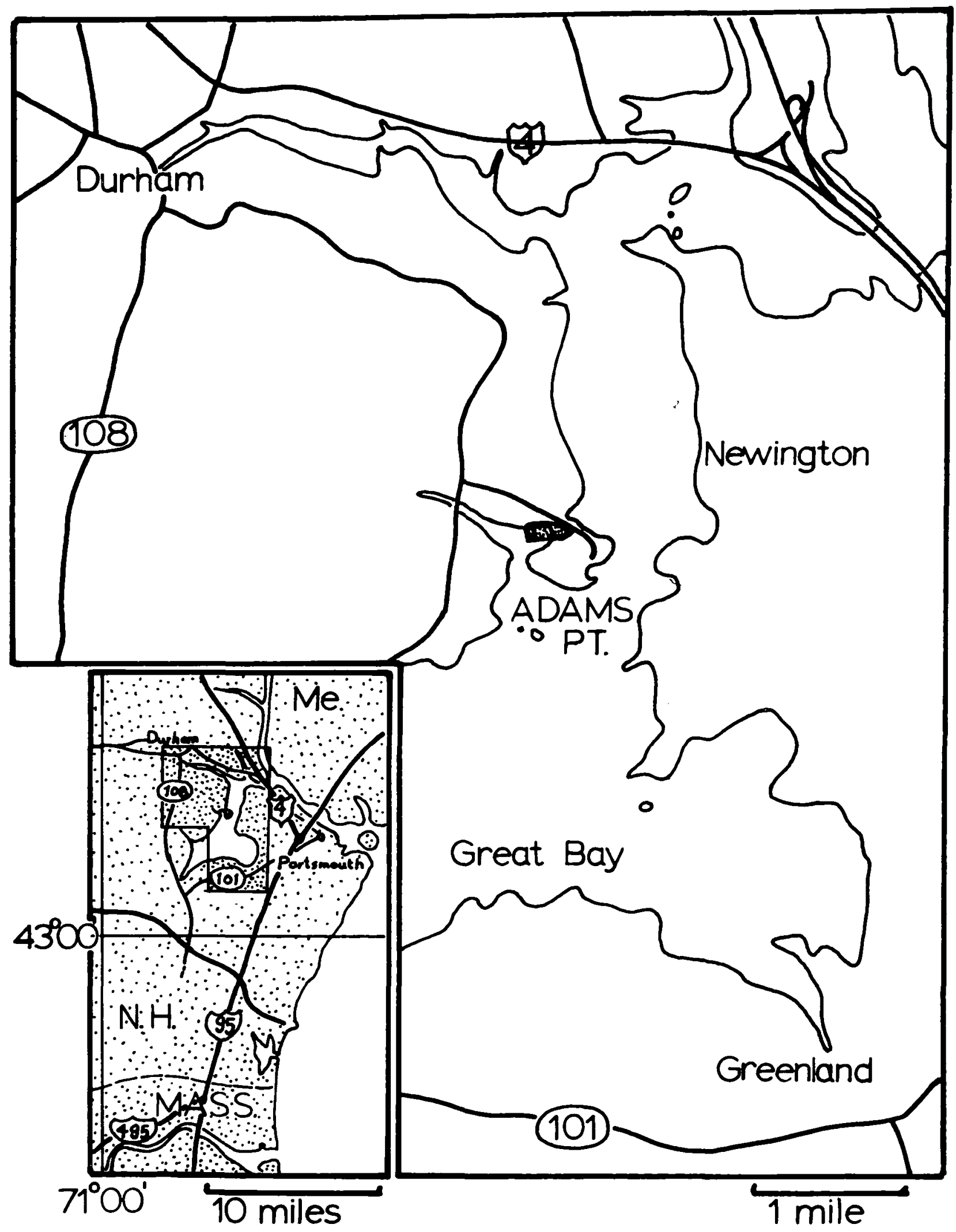

Figure 1. Great Bay, New Hampshire 


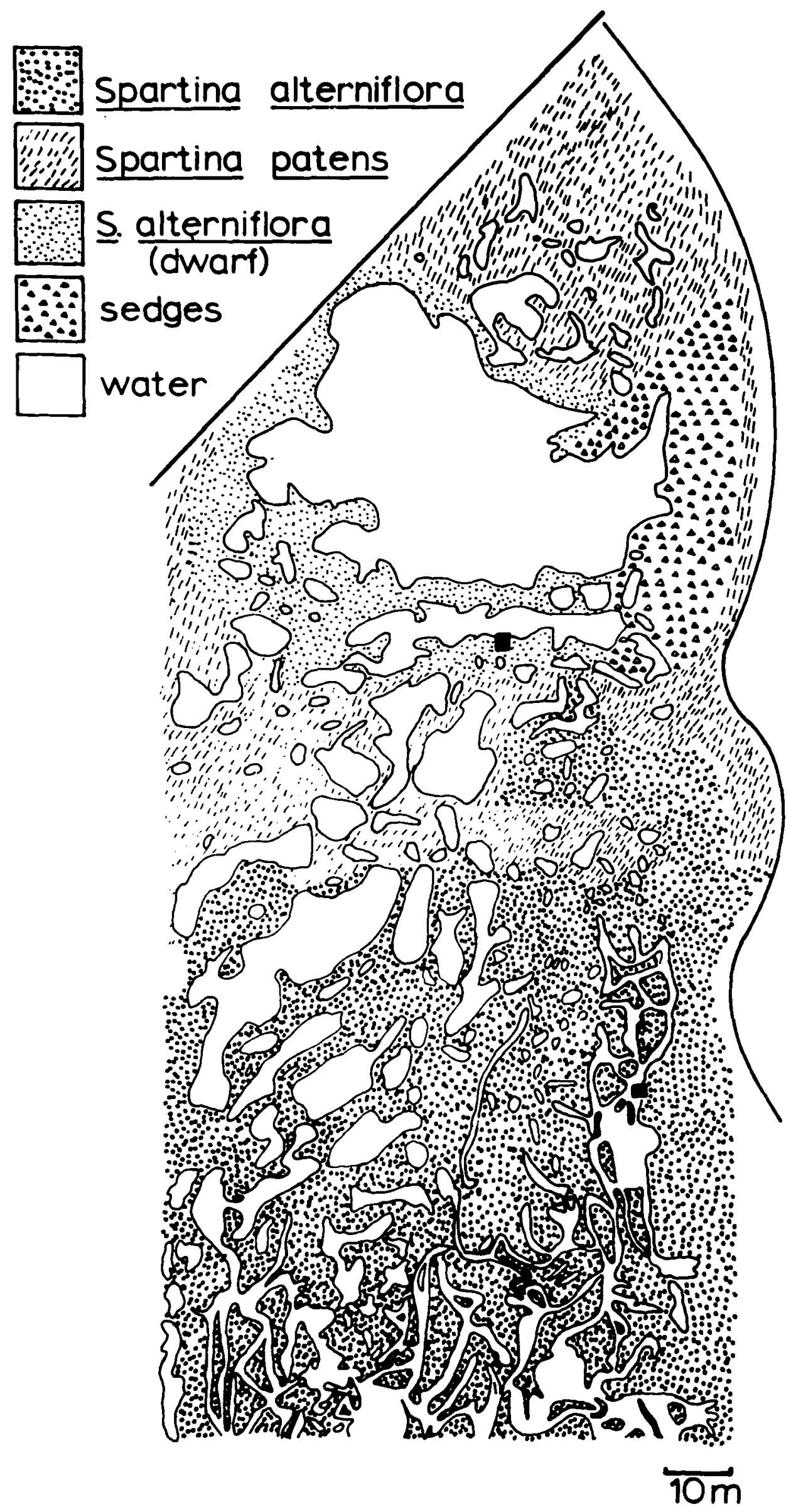

Figure 2. Tidal marsh 
SECTION IV

MATERIALS AND METHODS

SITE

Description of Sampling Area

Adams Point tidal marsh (Latitude $43^{\circ} 5^{\prime} 22^{\prime \prime} \mathrm{N}$.; Longitude $70^{\circ} 5^{\prime} 15^{\prime \prime} \mathrm{W}$. ) comprises about $300 \mathrm{~m}^{2}$ of intertidal wetlands at the north end of Great Bay, New Hampshire (see Figs. 1,2). Major features of the marsh, illustrated in Fig. 2, include extensive panne ponds surrounded by Spartina patens, dwarf Spartina alterniflora, and sedges (Scirpus sp.), as well as lesser numbers of other typical tidal marsh plants. This portion of the marsh, referred to below as "upper marsh" comprises the northeasternmost $100 \mathrm{~m}^{2}$ of the study area. The upper marsh contrasts sharply with the remainder of the area, referred to below as the "lower marsh". Here the dominant vegetation is tall Spartina alterniflora accompanied by small numbers of various broad-leaved plants including Atriplex sp., Salicornia sp., and Limonium sp. A small number of extensive panne ponds, here elongated in an east-west direction, are confined to the northern part of the lower marsh. In the remainder of the lower marsh, there are numerous narrow tidal channels $1 \mathrm{~m}$ deep draining to the southwest.

Although the maze-like configuration of these ditches including many blind channels and isolated sections of ditch may change from year to year due to ice action, the general drainage patterns remain consistent. One important drainage pattern includes a series of more or less parallel ditches and widened pools along the south edge of the sampling area in the lower marsh.

Although the algal flora of the marsh was not examined extensively from a taxonomic point of view, there are extensive seasonal developments of filamentous green algae (Cladophora sp.) and bluegreen algae around the margins of the panne ponds. Felt-like mats of Vaucheria occur along edges of ditches in the lower marsh.

By mid-February, the entire sampling area in Fig. 2 is covered by 15$45 \mathrm{~cm}$ of ice. In the coldest winters, ice extends to the bottom of the deepest pannes in the upper marsh.

At spring ice-out in March, the vegetative cover of the lower marsh is scoured free, the maze of channels is altered, and entire blocks of peat become dislodged from the underlying till and come to rest out on the tidal flat. 
The average tidal amplitude is approx. $2.5 \mathrm{~m}$ but varies considerably from predicted values due to the extensive tidal flats and the shallowness of the estuary. At times of spring high water the water level reaches the road edge at the top of Fig. 2 .

Quadrat System

To assist in development of Fig. 2, and to allow precise location of all collections, the system of quadrats, each $10 \mathrm{~m}$ square was surveyed across the entire area of Fig. 2. The corner of each square was marked by a wooden stake. Stakes were identifiable by painted numbers and letters.

FIELD METHODS

Permanent Station Platforms

Two elevated wooden platforms, each $1 \times 2 \mathrm{~m}$ were constructed in sites chosen for repeated sampling, to avoid unnecessary trampling of the tidal marsh peat (black squares in Fig. 2). One of these, in the upper marsh, extended to the southwest border of a panne pond, facilitating collections from the edge of the pond and the floating algal mats there. The second platform, in the lower marsh, extended to the edge of a narrow tidal creek, allowing repeated collections from the water running in that creek without disturbing sediments on either side. The platforms were large enough to accommodate three technicians and our assemblage of field equipment (see description below).

Equipment

$\underline{\mathrm{pH}}$ - Beckman portable field pH meter, model 1009, equipped with an electrode sufficiently long to allow measurement of vertical gradients in $\mathrm{pH}$ at all sampling locations.

Temperature - A $0.5 \mathrm{~m}$ rod, drilled at $5 \mathrm{~cm}$ intervals, accommodated miniature thermistor probes connected through a 10-point switch box to an Atkins Temperature Indicator (Model 3HOI-C10). Such an apparatus allowed nearly simultaneous measurement of vertical temperature gradients at any station.

Oxygen - Following the method of Burke 47 , we drew a water sample into the barrel of a $10 \mathrm{ml}$ syringe that had been greased with vacuum grease to prevent the plunger from slipping. Appropriate volumes of manganous sulfate, alkaline iodide solution, and ortho phosphoric acid were then drawn into the syringe in sequence in the field. We conducted the rest of the oxygen determination later in the laboratory. 
$\mathrm{H}_{2} \mathrm{~S}$ - Duxing the summer of $1970, \mathrm{H}_{2} \mathrm{~S}$ concentration was estimated using the Hach sulfide test kit, Model HS-1.

Salinity - We collected water samples in $50 \mathrm{ml}$ screw cap bottles for later laboratory determination of salinity.

Field Box - We designed and constructed a plywood weather-proof field box built to accomodate the $\mathrm{pH}$ meter, the thermistor and switchbox and probes, glassware for water samples, equipment and supplies for field oxygen and $\mathrm{H}_{2} \mathrm{~S}$ determination, and recording equipment.

Sampling for Ciliated Protozoa

Tubes - Collection tubes were $10 \mathrm{~cm}$ lengths of polyvinyl chloride nontoxic tubing, $2.5 \mathrm{~cm}$ I.D., that were filled and stoppered beneath the water surface. Ordinarily, each such tube, of an average volume of 18-20 $\mathrm{ml}$ when stoppered, provided 4-5 replicates for quantitative analysis of ciliate populations (see Laboratory Methods section). The proximity of the marsh station to the Jackson Estuarine Laboratory (less than $0.5 \mathrm{~km}$ ) permitted examination of tube contents within $1 \mathrm{hr}$ after collection.

Syringes - We collected water from the interstices of mats of filamentous green algae by drawing water from the mats into a $10 \mathrm{ml}$ syringe. Although not accurate quantitatively, due to the narrow aperture of the syringe, such technique allowed sampling from microhabitats not available to tube sampling.

Noland Bottles - By fitting a $250 \mathrm{ml}$ wide-mouth bottle with a 2-hole rubber stopper, each hole fitted with a V-shaped glass tube, and one of these fitted with a $0.5 \mathrm{~m}$ length of rubber tubing, we were able to aspirate into the bottle small volume samples from specific spots on the bottoms of panne ponds.

Bacteriological sampling - We drew $1 \mathrm{ml}$ samples of water into sterile $1.0 \mathrm{ml}$ tuberculin syringes that were capped and transported to the laboratory for dilution and inoculating of test cultures.

Time factor

General sampling - Except when conducting specific sequences of collections related to tidal factors (see description below), samples were collected at various times during daylight hours. Because of the proximity of the sampled area to the Jackson Estuarine Laboratory we were able to examine collections for ciliates $30 \mathrm{~min}-1 \mathrm{hr}$ after collection. Comparison of such collections with collections examined microscopically 
in the field immediately after sampling convinced us that there was no significant loss - or multiplication - of protozoa during the interval of transportation to the laboratory.

Relationship to tidal regime - We designed the timing of one series of collections to allow determination of effects of full moon spring tides and the resulting flooding of a pool in the upper marsh upon ciliate and bacterial populations. In these instances, time of day of each collection was constant (11:00 a.m.) and the particular day of each collection was chosen to allow collections both before and after initial flooding of the pool.

Relationship to lunar regime - We designed three series of collections to determine effects of full moon spring tides, neap tide, and new moon spring tide upon diurnal changes in ciliate and bacterial populations in a tidal channel in the lower marsh. We made three series of collections on each of three days in which full moon spring, neap, and new moon spring tides were predicted, and sampled the same station every three hours over a $24 \mathrm{hr}$ period.

Additional comments

We recorded all field data originally on mimeographed data sheets or on IBM portable dictaphone tape for later transfer and storage on Keysort punchcards $(12.8 \times 20.3 \mathrm{~cm})$.

IAABORATORY METHODS

\section{Chemical}

We determined salinity in the laboratory by one of three methods. We used a Hach chloride test kit, but found this less dependable than the standard Knudsen titration method. During 1971, all our measurements were made with an American Optical Company refractometer designed to allow measurement directly of salinity in parts per thousand. With an initial calibration to a water of known salinity as measured by the Knudsen method, and occasional recalibration, this instrument allowed determination of salinity on as little as 1 drop of water with an accuracy of \pm 1 part per thousand.

\section{Ciliates and Metazoa}

In order to identify and count ciliates in quantitative samples, we brought the original collection tubes to the Jackson Estuarine Iaboratory along with a $125 \mathrm{ml}$ bottle filled with water from the same water mass as that from which the collection tube was filled. After filtration, this additional water served as diluent (see technique described below). 
We assembled in a vertical series a glass funnel to hold a square of $1 \mathrm{~mm}$ mesh Nitex gauze and 4 Buchner funnels fitted with Nitex gauze circles of $505 \mu \mathrm{m}, 253 \mu \mathrm{m}, 153 \mu \mathrm{m}$, and $64 \mu \mathrm{m}$ mesh size respectively, held firmly in place with Tygon C-rings. These were spaced to allow use of an eyedropper conveniently and so as to drain into a $150 \mathrm{ml}$ beaker. We began filtration by pouring the sample into the $1 \mathrm{~mm}$ Nitex gauze so that any material that was held by the gauze was as close to the bottom of the cone as possible. Pouring was at a sufficiently slow rate so as to avoid overflow of the Buchner funnels. A volume of filtered water from the habitat, of an amount 4 times that of the original collection, was used to flush the filters to insure maximum passage of ciliates through the filter series into the beaker below. Routine inspection of filters indicated greater than $90 \%$ effectiveness of passage of ciliates through the series, while allowing retention on the filters of most of the organic debris and larger microorganisms that otherwise would interfere with the counting process.

After filtration finished (about $10 \mathrm{~min}$ ), we agitated the contents of the beaker until any solid matter was homogeniously distributed and then while still stirring vigorously, we poured $22.5 \mathrm{ml}$ aliquots into $4-5$ square plastic Petri dishes (Falcon No. 1012) inscribed with a grid of 36 squares, each $12 \mathrm{~mm}$ on edge. We prepared each Petri dish as a counting chamber by marking on the lower side 5 squares (a central square and 4 at the corners.)

Upon placing $22.5 \mathrm{ml}$ of the filtrate into the counting chamber, we placed the counting chamber on the stage of a dissecting microscope and allowed it to stand a few minutes until any remaining debris settled. Proceeding first with the central square and the remaining ones in a clockwise direction, we counted all organisms observed and identified them as far as possible. The data were recorded verbally on an IBM dictaphone and later transcribed onto punchcards.

To corroborate identifications mace during the analysis described above, we maintained cultures of all collections and many isolated species of ciliates. We employed various media, including rice grains, split peas, and proteose peptone. Carnivorous forms were grown using oxyrrhis marina (a dinoflagellate) or small uronematid ciliates as a food source. We maintained all cultures in a room held at $20^{\circ} \mathrm{C}$. We observed living individuals with a dissecting microscope and bright-field microscopes, corroborating cortical details by the nigrosinmercuric chloride formalin method 48,49 and the Chatton-Lwoff silver impregnation technic as modified by Corliss 50 , and nuclear morphology by an iron hematoxylin method and a modified Fuelgen nucleal reaction. We used a camera lucida, a calibrated ocular micrometer, and a Nikon automatic photomicroscope employing high contrast copy film to record observations of morphology. Because of the importance of species identification to the fulfillment of this project, 
it became necessary to make fundamental taxonomic revisions, develop family diagnoses, and construct binary keys to aid in identification of ciliates to family, and then to species.

Permanent preparations containing type material of new species discovered in this project have been deposited in the U.S. National Museum 51 .

Bacteriological Methods

We estimated concentration of bacteria in the $1 \mathrm{ml}$ samples described above by a procedure involving dilution of the sample in a nutrient liquid medium extended so that most of the tubes containing the highest dilution remained sterile after incubation 52 , specifically employing the basal medium and extinction dilution method adopted for seawater bacterial populations by Jannasch and Jones 53 . 
SECTION V

EXPERIMENTAL PHASE

\section{AUTECOLOGY}

During 1970 and 1971, I identified 103 species of ciliates, representing 41 families in 10 orders. Nearly a third of these were poorly known and four were new to science. These have been discussed in detail elsewhere ${ }^{51}$. During the summer of 1970, 79 species were identified from 175 collections. Duxing the summer of 1971, 82 species were identified from 102 collections. Species identified in sumer collections represent approximately $90 \%$ of the total number of species recorded from the Adams Pt. tidal marsh. The most commonly encountered species in 1971, Strombidium sulcatum, was identified in 73 of 102 collections. At the other extreme, 20 of the species recorded during 1971 were collected only once.

The following list employs the classification scheme used by Borror, $1973^{54}$. The numbers following each species denote the number of records during the summers of 1970 and 1971 respectively. Numbers indicated with an asterisk are instances of species recorded other than during those summers.

Members of some genera (Cyclidium, Euplotes, Pleuronema, and Vorticella) were not identified to species during quantitative sampling.

\section{Systematic list}

Order Gymnostomatida

Amphileptidae

Cryptopharynx setigerus

Litonotus cygnus

Litonotus sp.

Loxophylium chaetonotum

Loxophyllum setigerum

ChIamydodontidae

Chilodonella sp.

Chlamydodon lynchelliformis

Chlamydodon obliquus

Chlamydodon triquetris

colepidae

Coleps tesselatus

Didiniidae

Askenasia stellaris

Mesodinium pulex

$\begin{array}{rr}1 & 2 \\ 2 & 1 \\ 11 & 10 \\ 31 & 13 \\ 3 & 3 \\ & \\ 1 & 0 \\ 9 & 2 \\ 6 & 0 \\ 3 & 2 \\ & \\ 49 & 42 \\ & \\ 1 & 0 \\ 23 & 17\end{array}$


Dysteriidae

Dysteria marina

Dysteria monostyla

Trochilia sigmoides

Trochilioides recta

Enchelyidae

Chaenia sp.

Enchelyodon trepida

Holophrya coronata

Lacrymaria marina

Placus salinus

Metacystidae

Metacystis striata

Nassulidae

Nassula labiata

Nassula sp.

Prorodontidae

Prorodon marinus

Spathidiidae

Spathidium sp.

Stephanopogonidae

Stephanopogon apogon

Trachelocercidae

Trachelonema oligostriata

\begin{tabular}{rrr}
4 & & 5 \\
3 & & 5 \\
& $1 *$ & \\
3 & & 0 \\
& & \\
7 & & 4 \\
0 & & 2 \\
1 & & 1 \\
17 & & 8 \\
4 & & 8 \\
& & \\
4 & & 4 \\
& & \\
6 & & 6 \\
0 & & 2 \\
29 & & \\
29 & & \\
\hline 7 & & 4 \\
& & \\
2 & & 1 \\
2 & & 17
\end{tabular}

Order Trichostomatida

Colpodidae

Colpoda cucullus

Geleiidae

Geleia orbis

Geleia simplex

Plagiopylidae

Plagiopyla nasuta

Sonderia cyclostomata

Sonderia sinuata

Trimyemidae

Trimyema pleurispirale

$1 *$

$0 \quad 1$

146

$10 \quad 2$

$0 \quad 1$

$10 \quad 12$

01

Order Suctorida

Acinetidae

Acineta sp.

1 *

Order Hymenostomatida

Cinetochilidae

Cinetochilum margaritaceum

0

cohnilembidae

Cohnilembus verminus 
Frontonilidae

Frontonia fusca

Frontonia marina

Frontonia microstoma

Ophryoglenidae

Ophryoglena flava

Parameciidae

Paramecium calkinsi

Philasteridae

Paranophrys magna

Parauronema acutum

Porpostoma notatum

Pleuronematidae

Cyclidium marinum

Cyclidium plouneouri

Pleuronema coronatum

Pleuronema smalli

Pseudocohnilembidae

Paralembus hargisi

Paralembus marinus

Pseudocohnilembus longisetus

Tetrahymenidae

Paratetrahymena wassi

Uronematidae

Uronema filificum

Uronema marinum

Uronema sp.

Uropedalium pyriforme

$\begin{array}{rrr}0 & 3 \\ 40 & 38 \\ 2 & & 0 \\ & & \\ 2 & & 0 \\ & & \\ 7 & & 1 \\ & & \\ 1 & & 3 \\ 2 & & 5 \\ 4 & & 4 \\ & & \\ 27 & & 24 \\ 27 & & 24 \\ 17 & & 4 \\ 17 & & 4 \\ & & \\ 1 & & 0 \\ 1 & & 1 \\ & 1 * & \\ & & \\ & 1 * & \\ & & \\ 25 & & 33 \\ 8 & & 5 \\ 0 & & 1 \\ 7 & & 9\end{array}$

Order Peritrichida

Vaginicolidae

Cothurnia simplex

Vaginicola sp.

Vorticellidae

Vorticella nebulifera

Vorticella striata

Zoothamnium sp.

unid. swarmer

$\begin{array}{rrr} & 1 * & \\ 1 & & 1 \\ & & \\ 12 & & 5 \\ 12 & & 5 \\ 1 & & 0 \\ 0 & & 2\end{array}$

Order Heterotrichida

Condylostomatidae

Condylostoma arenarium

Metopidae

Metopus contortus

Peritromidae

Peritromus faurei 
Spirostomatidae

Gruberia lanceolata

Parablepharisma bacteriophorm

$32 \quad 23$

Parablepharisma chlamydophorum

Protocruzia depressa

Spirostomum sp.

47

16

21

$0 \quad 1$

Order Odontostomatida

Mylestomatidae

Mylestoma bipartitum

Order Oligotrichida

Halteriidae

Strombidium kahli

Strombidium latum

Strombidium purpureum

Strombidium styliferum

Strombidium sulcatum

Strombidium viride

Strobilidiidae

strobilidium caudatum

$\begin{array}{rr}7 & 1 \\ 16 & 4 \\ 2 & 1 \\ 12 & 12 \\ 32 & 73 \\ 0 & 2 \\ & \\ 0 & 2\end{array}$

Order Tintinnida

unid. sp.

3

3

Order Hypotrichida

Euplotidae

Aspidisca aculeata

Aspidisca baltica

Aspidisca sp.

Diophrys oligothrix

Diophrys scutum

Euplotes bisulcatus

Euplotes charon

Euplotes crassus

Euplotes harpa

Euplotes quinguecarinatus

Euplotes trisulcatus

Uronychia transfuga

Holostichidae

Holosticha diademata

Paraholosticha polychaeta

Trichotaxis pulchra

$21 \quad 12$

01

11

64

121

$0 \quad 1$

12

1 *

$2 \quad 2$

$0 \quad 1$

02

121

168

$1 *$

$1 *$

1 *

Gastrostyla pulchra

Histriculus similis

Oxytricha halophila

12 


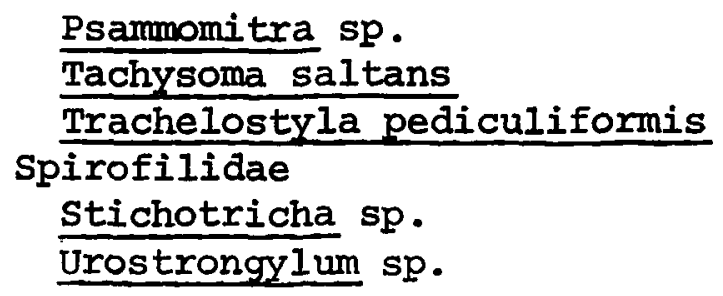

$\begin{array}{ccc}1 & & 0 \\ 11 & 1 * & \\ & & 7 \\ 1 & & \\ 1 & & 0 \\ & & 0\end{array}$

Correlation of Occurrences with Physical and Chemical Factors

Temperature - Since the overwhelming majority of collections were made during the warmer months, over a relatively narrow temperature range, I have attempted no correlations between ciliate occurrence or abundance and temperature. Although a vertical temperature gradient was often recorded in panne ponds (e.g. see Table 11), there was little evidence that concomitant vertical differences in ciliate distribution were the result of such temperature differences.

H2S concentration - Of 175 collections during the summer of 1970, $\mathrm{H}_{2} \mathrm{~S}$ concentration was measured in 48 instances. Most species occurred over a wide range of $\mathrm{H}_{2} \mathrm{~S}$ concentration $(0-5 \mathrm{ppm})$. In a few instances (Gruberia lanceolata and Uronema filificum), the species were recorded more regularly in areas of high sulfide levels (3-5 ppm). In a larger number of instances (Coleps tesselatus, Loxophyllum chaetonotum, Mesodinium pulex, Peritromus faurei, and Strombidium latum), there were apparent negative correlations - the species usually recorded in samples with relatively low $(0-2 \mathrm{ppm}) \mathrm{H}_{2} \mathrm{~S}$ concentration.

Hydrogen Ion Concentration - Although $\mathrm{pH}$ values in the marsh varied considerably (6.3-9.5), analysis of $\mathrm{pH}$ values associated with occurrences of the most frequently occurring species (those occurring in at least 10 samples each summer) reveal no significant correlation between $\mathrm{pH}$ and ciliate occurrence. Such findings are not unexpected ${ }^{53}$.

Salinity - Although rain water can collect in the panne ponds and temporarily reduce salinity in the tidal marsh, there are no permanent fresh water streams draining into the sample area, hence salinities remain at estuarine levels. During the summers of 1970 and 1971, most recorded salinities were between 22 and 33 parts per thousand (e.g. see Tables 1114). No summer samples were taken with salinities below 16 parts per thousand. Occurrence of the most frequently encountered species (e.g. Coleps tesselatus and Mesodinium pulex) show no correlation with salinity (see Table 1).

A frequently encountered hymenostome, uronema filificum, generally occurred more frequently, and reached higher concentrations in higher salinities (greater than 28 parts per thousand) than a closely related species, Uropedalium pyriforme (see Table 1). In 1970, they showed no 
overlap in distribution with relationship to salinity. In 1971, although there was some overlap, Uropedalium pyriforme occurred with greater regularity in waters of lower salinity than those inhabited by uronema filificum.

In a few instances (Prorodon marinus, Peritromus faurei, and strombidium latum, styliferum and sulcatum) the species were recorded more frequently in higher salinities (28-34 parts per thousand) than in waters of lower salinity (see Table 1). Strombidium sulcatum, for which the most data were available, seemed to show the strongest positive correlation with salinity. The small number of samples at salinities below 20 parts per thousand precluded any negative correlations between ciliate occurrence and salinity.

Oxygen concentration - In general, the more regularly occurring species showed no obvious correlation in either occurrence or in abundance with $\mathrm{O}_{2}$ concentration. In 1970 and 1971, Coleps tesselatus, Frontonia marina, Gruberia lanceolata and Peritromus faurei occurred over a wide range in $\mathrm{O}_{2}$ concentration and reached high numbers in samples saturated with $\mathrm{O}_{2}$ as well as in samples devoid of $\mathrm{O}_{2}$. Table 2 illustrates a typical situation of a ciliate apparently highly tolerant of variations in oxygen availability. Mesodinium pulex and prorodon marinus distribution in 1970 showed a slight positive correlation to $\mathrm{O}_{2}$ concentration, but showed no obvious correlation in 1971 (Table 3 ). In the case of Uronema filificum (Table 4), both the 1970 and the 1971 data indicate that this ciliate occurs more frequently, and reaches higher numbers the lower the oxygen concentration, reaching its greatest abundance at 0-1 ppm. Less regularly occurring species that similarly are tolerant of anoxic environments include Cohnilembus verminus, Histriculus similis, Paraplepharisma spp., Metopus contortus, Mylestoma bipartitum, Sonderia sinuata, Trachelonema oligostriata, and Uropedalium pyriforme. 1970 data indicate also that Stephanopogon apogon and Parauronema acutum similarly occur most frequently at low $\mathrm{O}_{2}$ concentrations.

Among the many species of the Oligotrich genus Strombidium, three of the more regularly occurring species (S. latum, styliferum, and sulcatum) showed differences in tolerance to $\mathrm{O}_{2}$ concentration. S. sulcatum apparently is tolerant to the entire range of $\mathrm{O}_{2}$ concentration, reaching high numbers throughout the range (Table 5).

Strombidium styliferum is capable of reaching high numbers at low $\mathrm{O}_{2}$ concentrations, but at a lower frequency of occurrence (Table 6). Strombidium latum is more regular at higher $\mathrm{O}_{2}$ concentrations, but not at the highest levels (Table 7). 


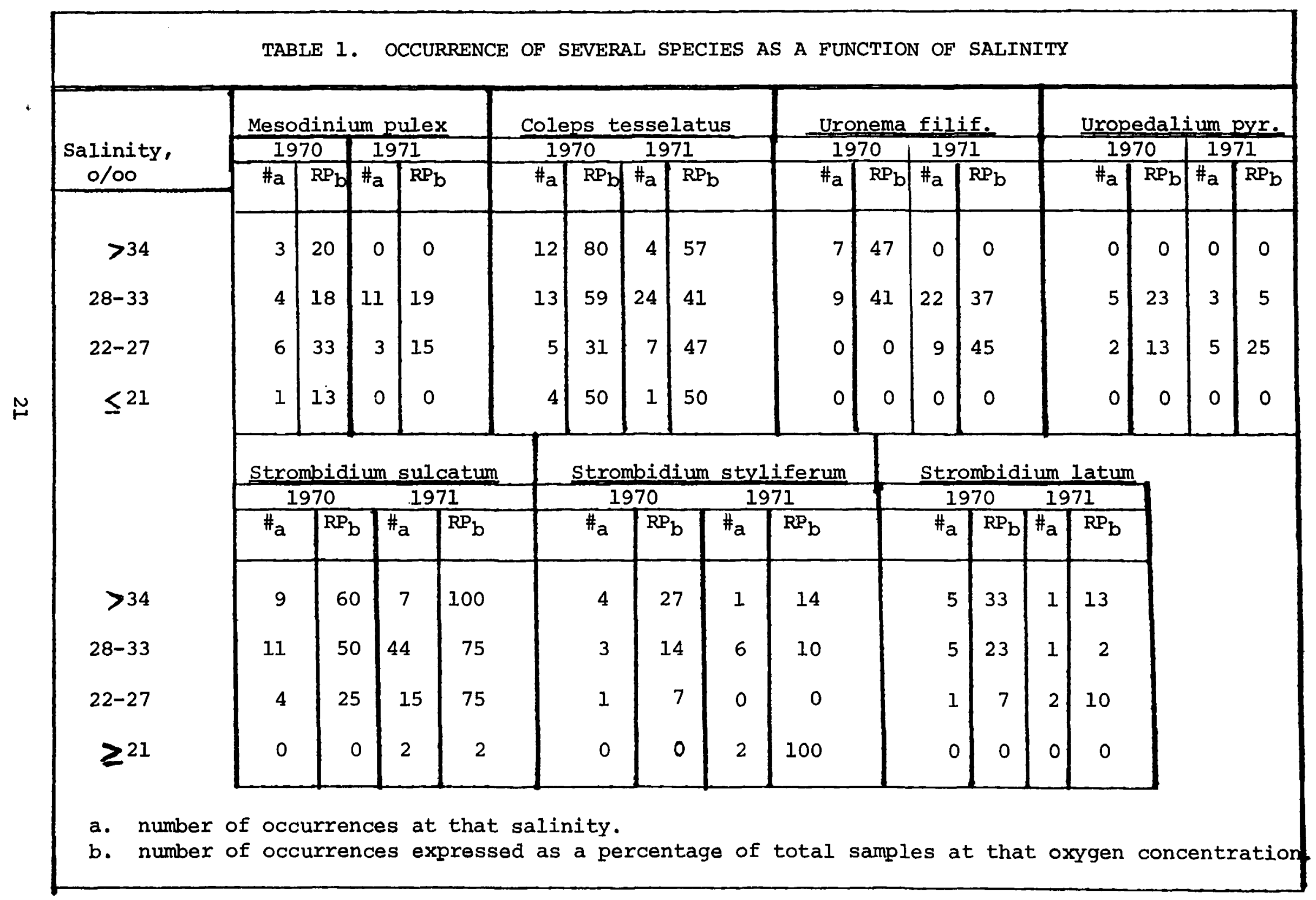


TABLE 2. COLEPS TESSEIATUS OCCURRENCE AND ABUNDANCE AS A FUNCTION OF OXYGEN CONCENTRATION

\begin{tabular}{|c|c|c|c|c|c|c|}
\hline \multirow[b]{2}{*}{$\begin{array}{l}\text { Oxygen, } \\
\text { ppm }\end{array}$} & \multicolumn{3}{|c|}{1970} & \multicolumn{3}{|c|}{1971} \\
\hline & $\#$ a & $\mathrm{RP}_{\mathrm{b}}$ & $\begin{array}{c}\text { conc. } \\
\text { cells/ } 10 \mathrm{ml} \\
\end{array}$ & $\# a$ & $\mathrm{RP}_{\mathrm{b}}$ & $\begin{array}{l}\text { conc.' } \\
\text { cells } / 10^{\prime} \mathrm{ml}\end{array}$ \\
\hline$>12$ & 6 & 27 & $\begin{array}{l}40,60,20 \\
420,80,20\end{array}$ & 8 & 90 & $\begin{array}{l}234,188,76 \\
20,19, x, x\end{array}$ \\
\hline $10-11$ & 0 & 0 & 0 & 2 & 100 & 8,21 \\
\hline $8-9$ & 5 & 100 & $\begin{array}{l}40,60,40 \\
180,880\end{array}$ & 2 & 50 & 20,207 \\
\hline $6-7$ & 3 & 38 & $40,120,180$ & 3 & 75 & $37,4, x$ \\
\hline $4-5$ & 4 & 67 & $20,60,80,100$ & 1 & 50 & 28 \\
\hline $2-3$ & 2 & 29 & 60,200 & 6 & 67 & $\begin{array}{l}107,80,4, \\
32,6,18\end{array}$ \\
\hline $0-1$ & 6 & 40 & $\begin{array}{l}20,40,60 \\
80,80,100\end{array}$ & 8 & 25 & $\begin{array}{l}230,400,80, \\
20,46,160, x, x\end{array}$ \\
\hline
\end{tabular}

a. number of occurrences at that oxygen concentration

b. number of occurrences expressed as a percentage of total samples at that oxygen concentration 
TABLE 3. MESODINIUM PULEX OCCURRENCE AND ABUNDANCE

AS A FUNCTION OF OXYGEN CONCENTRATION

\begin{tabular}{|c|c|c|c|c|c|c|}
\hline \multirow[b]{2}{*}{$\begin{array}{c}\text { Oxygen, } \\
\text { ppm }\end{array}$} & \multicolumn{3}{|r|}{1970} & \multicolumn{3}{|r|}{1971} \\
\hline & $\#_{a}$ & $R P_{b}$ & $\begin{array}{c}\text { conc.' } \\
\text { cells/10 ml }\end{array}$ & $\#_{a}$ & $\mathrm{RP}_{\mathrm{b}}$ & $\begin{array}{c}\text { conc. } \\
\text { cells/10 ml }\end{array}$ \\
\hline$>12$ & 6 & 35 & $\begin{array}{l}1,260,60 \\
100,80,40\end{array}$ & 0 & 0 & 0 \\
\hline $10-11$ & 0 & 0 & 0 & 1 & 50 & 3 \\
\hline $8-9$ & 1 & 20 & 40 & 2 & 50 & 40,9 \\
\hline $6-7$ & 1 & 13 & 20 & 1 & 25 & 8 \\
\hline $4-5$ & 1 & 17 & 40 & 0 & 0 & 0 \\
\hline $2-3$ & 1 & 14 & 40 & 2 & 22 & 9,18 \\
\hline $0-1$ & 3 & 20 & $60,40,20$ & 4 & 13 & $18,1, x, x$ \\
\hline
\end{tabular}

a. number of occurrences at that oxygen concentration

b. number of occurrences expressed as a percentage of total samples at that oxygen concentration 
TABLE 4. URONEMA FIIIFICUM OCCURRENCE AND ABUNDANCE AS A FUNCTION OF OXYGEN CONCENTRATION.

\begin{tabular}{|c|c|c|c|c|c|c|}
\hline \multirow[b]{2}{*}{$\begin{array}{c}\text { Oxygen, } \\
\text { ppm }\end{array}$} & \multicolumn{3}{|c|}{1970} & \multicolumn{3}{|c|}{1971} \\
\hline & $\#_{a}$ & $\mathrm{RP}_{\mathrm{b}}$ & $\begin{array}{c}\text { conc.:' } \\
\text { cells } / 10 \mathrm{ml}\end{array}$ & $\#_{a}$ & $\mathrm{RP}_{\mathrm{b}}$ & $\begin{array}{c}\text { conc.' } \\
\text { cells } / 10 \mathrm{ml} \\
\end{array}$ \\
\hline$>12$ & 2 & 12 & 20,60 & 0 & 0 & 0 \\
\hline $10-11$ & 0 & 0 & 0 & 1 & 50 & 8 \\
\hline $8-9$ & 0 & 0 & 0 & 0 & 0 & 0 \\
\hline $6-7$ & 2 & 25 & 40,20 & 1 & 25 & 4 \\
\hline $4-5$ & 3 & 50 & $80,140,40$ & 0 & 0 & 0 \\
\hline $2-3$ & 0 & 0 & 0 & 4 & 44 & $20,18,18,8$ \\
\hline $0-1$ & 7 & 47 & $\begin{array}{l}20,20,20,80 \\
40,740,100\end{array}$ & 18 & 56 & $\begin{array}{l}15,200,5,5,9, \\
36,4,400,18, \\
12,18,18,1600, \\
x, x, x, x\end{array}$ \\
\hline
\end{tabular}

a. number of occurrences at that oxygen concentration

b. number of occurrences expressed as a percentage of total samples at that oxygen concentration 
TABLE 5. STROMBIDIUM SULCATUM OCCURRENCE AND ABUNDANCE AS A FUNCTION OF OXYGEN CONCENTRATION.

\begin{tabular}{|c|c|c|c|c|c|c|}
\hline \multirow[b]{2}{*}{$\begin{array}{l}\text { Oxygen, } \\
\text { ppm }\end{array}$} & \multicolumn{3}{|r|}{1970} & \multicolumn{3}{|r|}{1971} \\
\hline & $\#_{a}$ & $\mathrm{RP}_{\mathrm{b}}$ & $\begin{array}{l}\text { conc. } \\
\text { cells/10 ml }\end{array}$ & $\# \mathbf{a}$ & $\mathrm{RP}_{\mathrm{b}}$ & $\begin{array}{c}\text { conc.' } \\
\text { cells } / 10^{\prime} \mathrm{ml}\end{array}$ \\
\hline$>14$ & 4 & 24 & $\begin{array}{l}40,300,400, \\
1500\end{array}$ & 3 & 38 & $40,565, x$ \\
\hline $12-13$ & 0 & 0 & 0 & 2 & 75 & $20, x$ \\
\hline $10-11$ & 0 & 0 & 0 & 2 & 100 & 2,35 \\
\hline $8-9$ & 1 & 20 & 60 & 3 & 75 & $420,468, x$ \\
\hline $6-7$ & 3 & 38 & $20,40,80$ & 2 & 50 & 52,1765 \\
\hline $4-5$ & 3 & 50 & $60,60,160$ & 2 & 100 & 24,28 \\
\hline $2-3$ & 2 & 29 & 100,180 & 9 & 100 & $\begin{array}{l}39,540,5,356, \\
10,12,920,71 \\
576\end{array}$ \\
\hline$a-1$ & 8 & 53 & $\begin{array}{l}1500,100,60 \\
220,20,180 \\
20,7900\end{array}$ & 27 & 84 & $\begin{array}{l}35,5,21,1360, \\
240,16,18,19, \\
14,600,800, \\
1250,1037,561, \\
336,40,7000, \\
60,8,9,4,9,15, \\
x, x, x\end{array}$ \\
\hline
\end{tabular}

a. number of occurrences at that oxygen concentration

b. number of occurrences expressed as a percentage of total samples at that oxygen concentration 
TABLE 6. STROMBIDIUM STYLIFERUM OCCURRENCE AND ABUNDANCE AS A FUNCTION OF OXYGEN CONCENTRATION.

\begin{tabular}{|c|c|c|c|c|c|c|}
\hline \multirow[b]{2}{*}{$\begin{array}{l}\text { Oxygen } \\
\text { ppm }\end{array}$} & \multicolumn{3}{|c|}{1970} & \multicolumn{3}{|c|}{1971} \\
\hline & $\#_{a}$ & $R P_{b}$ & $\begin{array}{c}\text { conc.:' } \\
\text { cells } / 10 \mathrm{ml} \\
\end{array}$ & $\#_{a}$ & $\mathrm{RP}_{\mathrm{b}}$ & $\begin{array}{c}\text { conc.: } \\
\text { cells } / 10 \mathrm{mI} \\
\end{array}$ \\
\hline$>14$ & 4 & 24 & $1,40,60,260$ & 3 & 38 & $17,40, x$ \\
\hline $13-14$ & 0 & 0 & 0 & 1 & 100 & 20 \\
\hline $12-13$ & 1 & 33 & 20 & 1 & 50 & $\mathbf{x}$ \\
\hline $10-11$ & 0 & 0 & 0 & 0 & 0 & 0 \\
\hline $8-9$ & 2 & 40 & 20,20 & 0 & 0 & 0 \\
\hline $6-7$ & 0 & 0 & 0 & 0 & 0 & 0 \\
\hline $4-5$ & 0 & 0 & 0 & 0 & 0 & 0 \\
\hline $2-3$ & 1 & 14 & 40 & 1 & 11 & 18 \\
\hline $0-1$ & 2 & 13 & 40,60 & 3 & 9 & $1,54,80$ \\
\hline
\end{tabular}

a. number of occurrences at that oxygen concentration

b. number of occurrences expressed as a percentage of total samples at that oxygen concentration 
TABLE 7. STROMBIDIUM IATUM OCCURRENCE AND ABUNDANCE AS A FUNCTION OF OXYGEN CONCENTRATION.

\begin{tabular}{|c|c|c|c|c|c|c|}
\hline \multirow[b]{2}{*}{$\begin{array}{c}\text { Oxygen, } \\
\text { ppm }\end{array}$} & \multicolumn{3}{|c|}{1970} & \multicolumn{3}{|c|}{1971} \\
\hline & $\#_{a}$ & $R P_{b}$ & $\begin{array}{c}\text { conc. } \\
\text { cells } / 10 \mathrm{ml}\end{array}$ & $\#_{a}$ & $\mathrm{RP}_{\mathrm{b}}$ & $\begin{array}{c}\text { conc. } \\
\text { cells } / 10 \mathrm{ml}\end{array}$ \\
\hline$>14$ & 1 & 6 & 180 & 0 & 0 & 0 \\
\hline $13-14$ & 0 & 0 & 0 & 1 & 100 & 20 \\
\hline $12-13$ & 2 & 67 & 140,800 & 1 & 50 & 4 \\
\hline $10-11$ & 0 & 0 & 0 & 1 & 50 & 4 \\
\hline $8-9$ & 2 & 40 & 20,40 & 0 & 0 & 0 \\
\hline $6-7$ & 2 & 25 & 20,140 & 0 & 0 & 0 \\
\hline $4-5$ & 2 & 33 & 20,80 & 0 & 0 & 0 \\
\hline $0-1$ & 2 & 13 & 20,700 & 2 & 6 & 1,80 \\
\hline
\end{tabular}

a. number of occurrences at that oxygen concentration

b. number of occurrences expressed as a percentage of total samples at that oxygen concentration 
SYNECOLOGY

Faunal Differences Between Upper and Lower Marsh

As a result of an initial survey of the sampling area (Fig. 2), and establishment of a map coordinate system for the grid of $10 \mathrm{~m}$ square quadrats in the marsh, it was possible to determine microdistributional differences for all species identified. Some similarities and differences of possible ecological significance were noted between ciliate faunas of upper marsh and lower marsh (both terms defined in Materials and Methods). Table 8 allows comparison of the degree of uniqueness of ciliate faunas of these two zones based on nearly equal numbers of collections. Table 9 allows comparison of locomotory types represented by species unique to either the upper marsh or the lower marsh. For instance, Strombidium purpureum and $S$. viride are planktonic; that is, they swim and feed independent of any substratum and often occur high in the water colum away from the bottom. They were identified only from samples collected in the upper marsh. By contrast, strombidium kahli, Trimyema pleurispirale, tintinnids, and Peritrich swarmers, also planktonic, were identified only in samples collected in the lower marsh.

In a number of instances (indicated by an asterisk following the name in Table 9), there were cases of two or more members of the same genus apparently separated microgeographically within the marsh. Although the more benthic Strombidium sulcatum and S. latum were ubiquitous, three other species were separated microgeographically. Two similar species of Euplotes (see Table 9) were also apparently microgeographically separated. These two species are so similar morphologically that greater magnification than that used in quantitative examination of samples is necessary for species identification. The microdistributional difference between the two species of Dysteria is particularly intriguing inasmuch as each was identified in five samples, one from the upper marsh and one from the lower marsh. The morphological differences, as well as documented uniformity within a species is fairly well understood ${ }^{5}$.

Table 10 is a summary of a different type of analysis of faunal differences between the upper and lower marsh. In this instance, only those species that occurred relatively frequently and in both halves of the sampling area were analyzed.

Physical and Biological Parameters of a patens-panne Pond

Table 11 summarizes data compiled from collections made at approx. Il a.m. on July 5, 9, 12, and 16, 1971. On each day, I made nearly simultaneous collections at the water surface, at the surface of the substratum, and at midwater level near the edge of a panne pond in the upper marsh (righthand black square in Fig. 2). The first two collections, on July 5 and 
TABLE 8. FAUNAL DIFEERENCES BETWEEN UPPER AND LOWER MARSH.

Comparison of endemism of upper marsh (patens-panne zone) and lower marsh (intertidal altemiflora zone).

\begin{tabular}{|c|c|c|c|c|c|c|c|c|}
\hline \multirow[b]{2}{*}{ Zones } & \multirow[b]{2}{*}{$\# \operatorname{col} 1}$. & \multirow{2}{*}{$\begin{array}{l}\text { \# species } \\
\text { recorded }\end{array}$} & \multicolumn{5}{|c|}{$\begin{array}{l}\text { unique species, } \\
\text { times recorded }\end{array}$} & \multirow[b]{2}{*}{ endemism, 8} \\
\hline & & & 1 & 2 & 3 & 4 & 5 & \\
\hline upper marsh & 45 & 82 & 10 & 5 & 0 & 0 & 1 & 19.5 \\
\hline lower marsh & 54 & 83 & II & $I$ & 2 & 3 & 1 & 21.7 \\
\hline total & 102 & 99 & & & & & & \\
\hline
\end{tabular}


TABLE 9. LOCOMOTORY TYPES REPRESENTED BY SPECIES UNIQUE TO EITHER UPPER MARSH OR LOWER MARSH

\begin{tabular}{|c|c|c|}
\hline \multirow{2}{*}{$\begin{array}{l}\text { Locomotory } \\
\text { type }\end{array}$} & \multicolumn{2}{|c|}{ Species } \\
\hline & Upper marsh & Lower marsh \\
\hline thigmotactic & $\begin{array}{l}\text { Cryptopharynx } \\
\text { Chlamydodon } \text { syncheligerus } \\
\frac{\text { Cinetochilum }}{\text { Dysgaritaceum }} \\
\frac{\text { Dysteria marina* }}{\text { Euplotes }} \frac{\text { quinquecarinatus* }}{\text { Aspidisca }} \\
\frac{\text { baltica }}{\text { Protocruzia depressa }}\end{array}$ & $\begin{array}{l}\text { Vaginicola sp. } \\
\text { Litonotus } \\
\text { Stephanopogon } \\
\frac{\text { Oxytricha }}{\text { halophila }} \\
\text { Dysteria monostyla* } \\
\text { Euplotes } \\
\text { Diophrys } \\
\text { bisulcatus* }\end{array}$ \\
\hline intermediate & $\begin{array}{l}\text { Paralembus spp. } \\
\text { Paramecium calkinsi } \\
\text { Spriostomum sp. } \\
\text { Uronychia transfuga } \\
\text { Geleia orbis } \\
\text { Enchelyodon trepida } \\
\text { Plagiopyla nasuta }\end{array}$ & $\begin{array}{l}\text { Holophrya coronata } \\
\text { Sonderia cyclostomata } \\
\text { Uronema sp. } \\
\text { Chaenia sp. } \\
\text { Cohnilembus verminus } \\
\text { Porpostoma notatum }\end{array}$ \\
\hline planktonic & $\begin{array}{l}\text { Strombidium } \\
\text { Strombidium virpureum } \\
\text { viride* }\end{array}$ & $\begin{array}{l}\frac{\text { Strombidium kahli }}{\text { Trimyema pleurispirale }} \\
\text { tintinnids } \\
\text { peritrich swarmers }\end{array}$ \\
\hline
\end{tabular}

* a member of at least two species in a genus separated microgeographically 
TABLE 10. FAUNAL DIFFERENCES BETWEEN UPPER AND LOWER MARSH. Occurrences of regularly encountered species in upper marsh (patens-panne zone) and lower marsh (intertidal alterniflora zone).

\begin{tabular}{|c|c|c|c|c|}
\hline \multirow[b]{2}{*}{ Species } & \multicolumn{2}{|c|}{ Occurrences } & \multirow[b]{2}{*}{ Total } & \multirow[b]{2}{*}{$\begin{array}{c}\text { Chi-square } \\
\text { value }\end{array}$} \\
\hline & $\begin{array}{l}\text { Upper } \\
\text { marsh }\end{array}$ & $\begin{array}{l}\text { Lower } \\
\text { marsh }\end{array}$ & & \\
\hline Strombidium sulcatum & 29 & 44 & 73 & 0.486 \\
\hline Coleps tesselatus & $\underline{27}$ & 15 & 42 & $6.979 *$ \\
\hline Frontonia marina & 12 & 26 & 38 & 2.360 \\
\hline Uronema filificum & 7 & $\underline{26}$ & 33 & $6.920 *$ \\
\hline Prorodon marinus & 12 & 17 & 29 & 0.090 \\
\hline Gruberia lanceolata & 7 & 16 & 23 & 1.592 \\
\hline Mesodinium pulex & 9 & 8 & 17 & 0.537 \\
\hline Trachelonema oligostriata & 4 & 13 & 17 & 2.922 \\
\hline Peritromus faurei & 8 & 7 & 15 & 0.530 \\
\hline Condylostoma arenarium & 8 & 5 & 13 & 1.653 \\
\hline $\begin{array}{l}\text { Total number of } \\
\text { collections }\end{array}$ & 45 & 57 & 102 & \\
\hline
\end{tabular}

* significant at 0.01 level of probability (D.F. = 1) 
TABLE 11. PHYSICAL AND BIOLOGICAL PARAMETERS OF A PATENS-PANNE POND. Effect of flooding by full moon spring high waters upon physical factors, bacterial concentration, ciliates and micrometazoa.

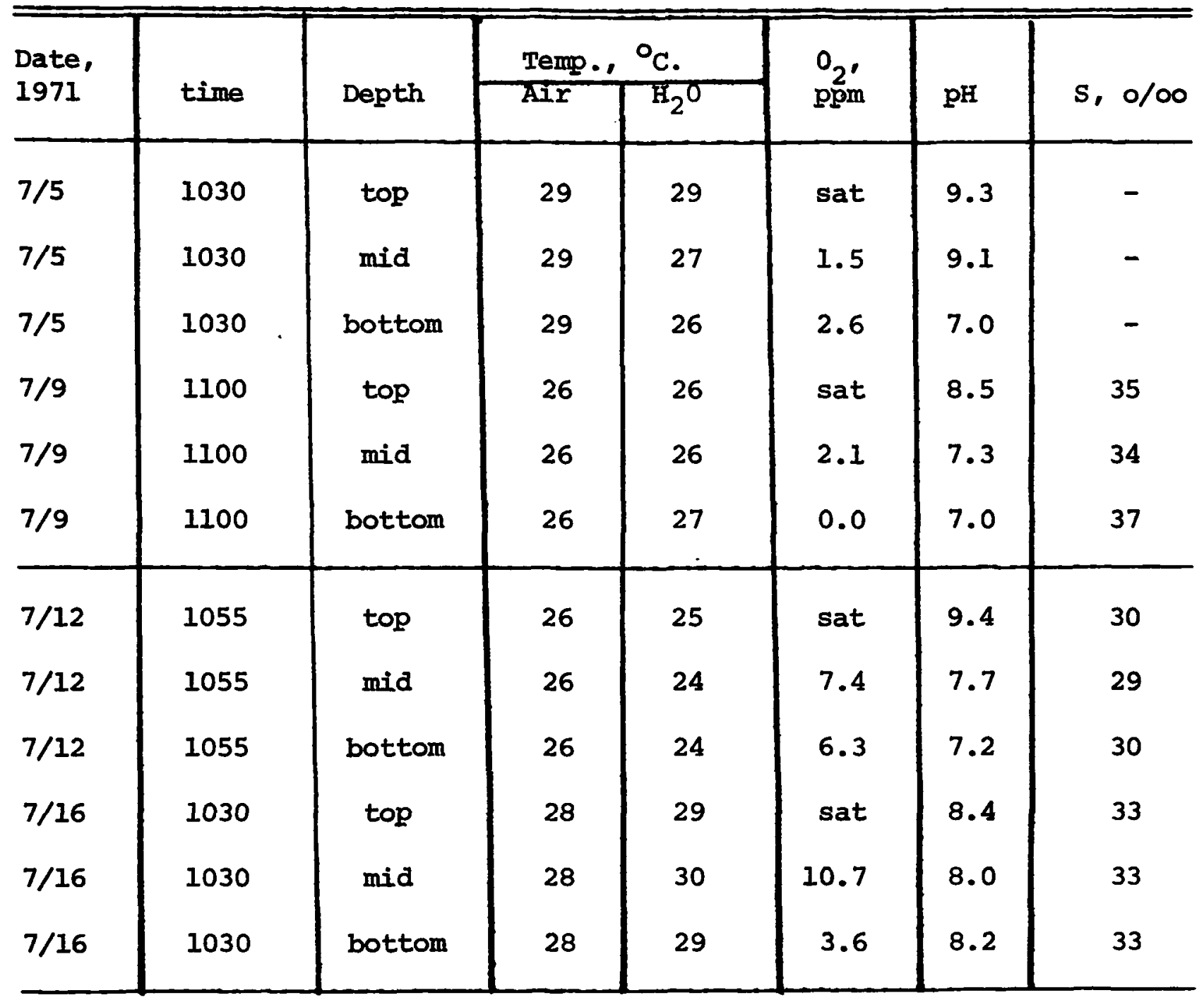


TABLE 11, cont'd. RHYSICAL AND BIOLOGICAL PARAMETERS OF A RATENS-PANNE POND.

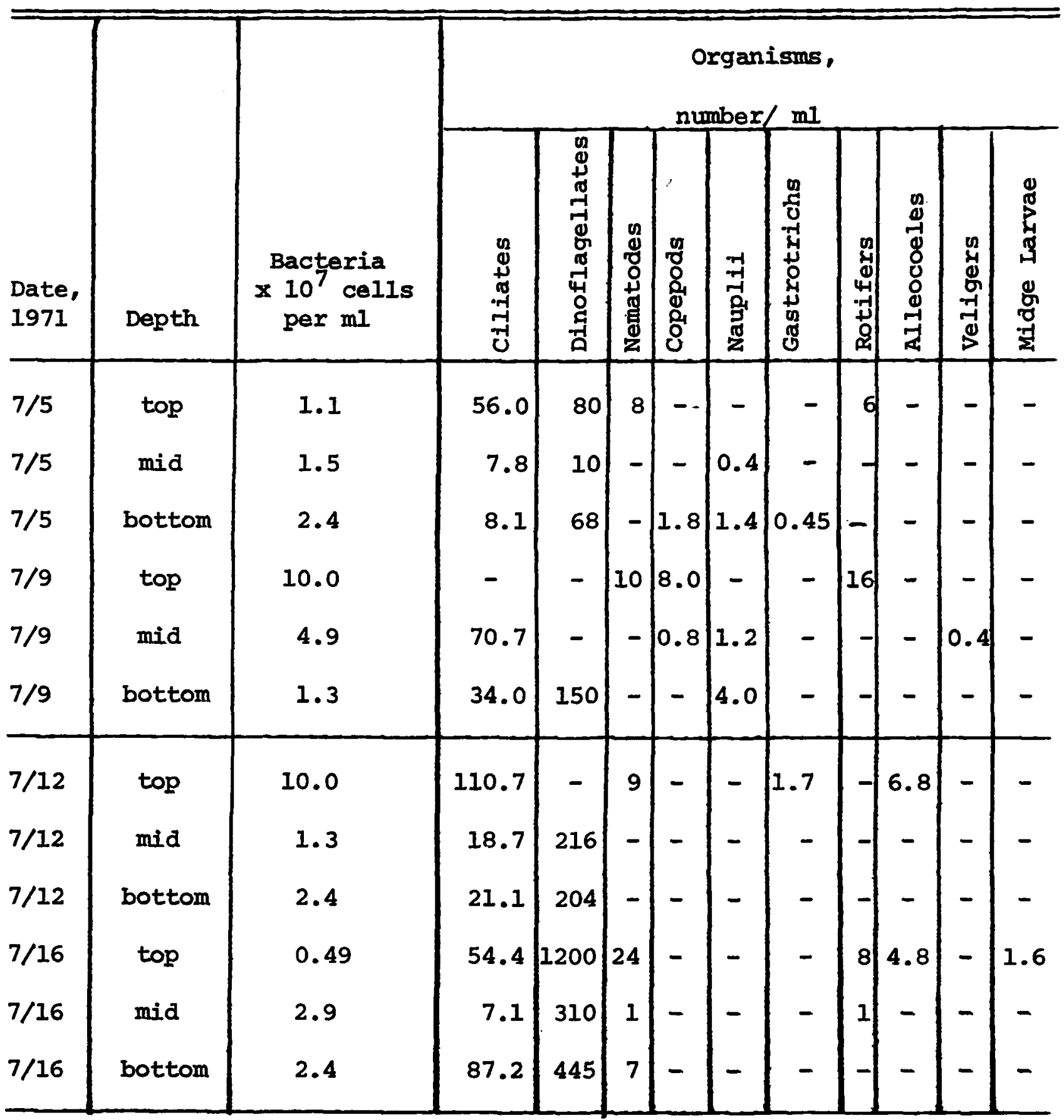


9, were taken toward the end of a 2-week period dominated by a neap tide cycle, during which no water exchange occurred between the panne pond and the ebb and flow of the tide. In other words, the station was a tidal pool isolated from the effects of tidal.flushing over a period in excess of a week. The samples of July 12 were collected following a session of full moon spring tides whose amplitude $(+2.47 \mathrm{~m})$ exceeded the height of the pool level $(+2.41 \mathrm{~m})$, thus allowing influx of tidal water from the estuary, and a resulting mixing of the pool water. Direct microscopic counts of ciliates, dinoflagellates, and micrometazoa were then compared with estimates of bacterial abundance and summarized in Table 11.

Physical and Chemical Factors - Except for a brief increase in depth at time of actual flushing at high tide, water depth at the station remained constant throughout the series of samples. We made all collections at the same time of day. There was relatively little change in air and water temperature during the period. Although salinity data are incomplete, salinity apparently fell during flushing, suggesting that evaporation during the period prior to flushing had led to higher salinities than those in the estuary. Hyarogen ion concentration generally decreased with depth in the pool and was most variable in mid-water. It was relatively constant at the top and bottom stations, and did not show correlation with flushing of the spring tides. Oxygen was at saturation or above throughout the series, due to photosynthetic activity of the heavy mats of Cladophora near the water surface. At middle levels and at the bottom, $\mathrm{O}_{2}$ concentration was relatively low before flushing and rose after flushing by the spring tide.

Biological Factors - Numbers of species of ciliates were highest in the surface mats of algae and on the surface of the substratum, correlated with increased niche diversity. Ciliate numbers were lowest in mid-water where strombidium sulcatum dominated. There appeared to be an increase in diversity on the bottom following flushing, associated with a rise in $\mathrm{O}_{2}$ concentration there, with dinoflagellates and bacteria about constant.

Concentrations of ciliates were highest at the surface and on the bottom. A pulse in concentration in midwater occurred following the $\mathrm{O}_{2}$ increase associated with flushing.

Dinoflagellate numbers increased slightly after flushing. Their abundance apparently was not related to their position in the water column except one pulse in the Cladophora mat. There were as many dinoflagellates at mid-water as on the bottom.

Numbers of copepods and copepod nauplii diminished upon flushing. There appeared to be no effect of flushing on rotifers and nematodes; they occurred primarily within interstices of the Cladophora mat. One veliger was seen in mid-water before flushing. Flatworms were not observed before flushing, but were seen on the bottom afterwards. 
There appeared to be no effects of tidal flushing upon bacterial numbers as measured by Most probable Number counts in our dilution series. The only exception was a pulse in bacterial numbers in the Cladophora mat. Numbers of bacteria remained fairly constant at mid-water and on the bottom.

Physical and Biological Parameters in the Lower Marsh During a Tide

Effects of a Full Moon Spring Tide - Table 12 summarizes data from analysis of a series of samples collected every three hours on 6 July 1971 at the time of full moon spring tides. Samples from the water surface and the substratum-water interface of a tidal channel (at a station indicated by the black square in the lower marsh in Fig. 2) were examined microscopically for ciliates, dinoflagellates, and micrometazoa, and correlated with bacterial abundance as determined by Most Probable Number analysis (see Materials and Methods section). The collection series allowed comparison of numbers of organisms in the water surging through the tidal channel on the ebb and the flood. Simultaneous with collections at the lower marsh station, we also analyzed a sample from the extreme lower end of the tidal marsh beyond the extent of the Spartina peat (southwest beyond the area illustrated in Fig. 2). We made no collections at high water since at that time water was not confined simply to the tidal ditches, but covered the platform entirely.

Physical and Chemical Factors - During the two full moon spring tidal cycles of July 6 , water temperature was uniformly $3-9^{\circ} \mathrm{C}$ lower in the forenoon, particularly on the ebb or at low water. $\mathrm{O}_{2}$ conc. remained uniformly generally nearly zero, rising to about $8 \mathrm{ppm}$ in the evening flood tide. Salinity ranged between 25-29 parts per thousand, with little regular variation. The $\mathrm{pH}$ at the water-substratum interface was generally approx. 0.2 units lower than at the water surface. The water coursing through the tidal channel on the ebb tide usually was about 0.5 - 1.0 units lower than the water at flood tide. Intermediate values were recorded at low tide.

Biological Factors - Ciliates in the tidal channel in the lower marsh were considerably more numerous, and usually represented by more species along the substratum-water interface than at the water surface. Ciliate numbers at the water surface usually were below that reached by populations in the patens-panne pond. In general, there were higher numbers of species, at greater concentrations, on the ebb tide than on the flood. Surface mud of the channel station at the lower edge of the tidal marsh contained considerably fewer species of ciliates and sometimes none at a11.

Dinoflagellates were not present in significant numbers in any of the collections. Micrometazoa essentially were restricted to the substratumwater interface. 
TABLE 12. PHYSICAL AND BIOLOGICAL PARAMETERS IN THE LOWER MARSH DURING A TIDE. Effect of a full moon spring tide cycle upon physical factors, bacterial concentration, ciliates, and micrometazoa.

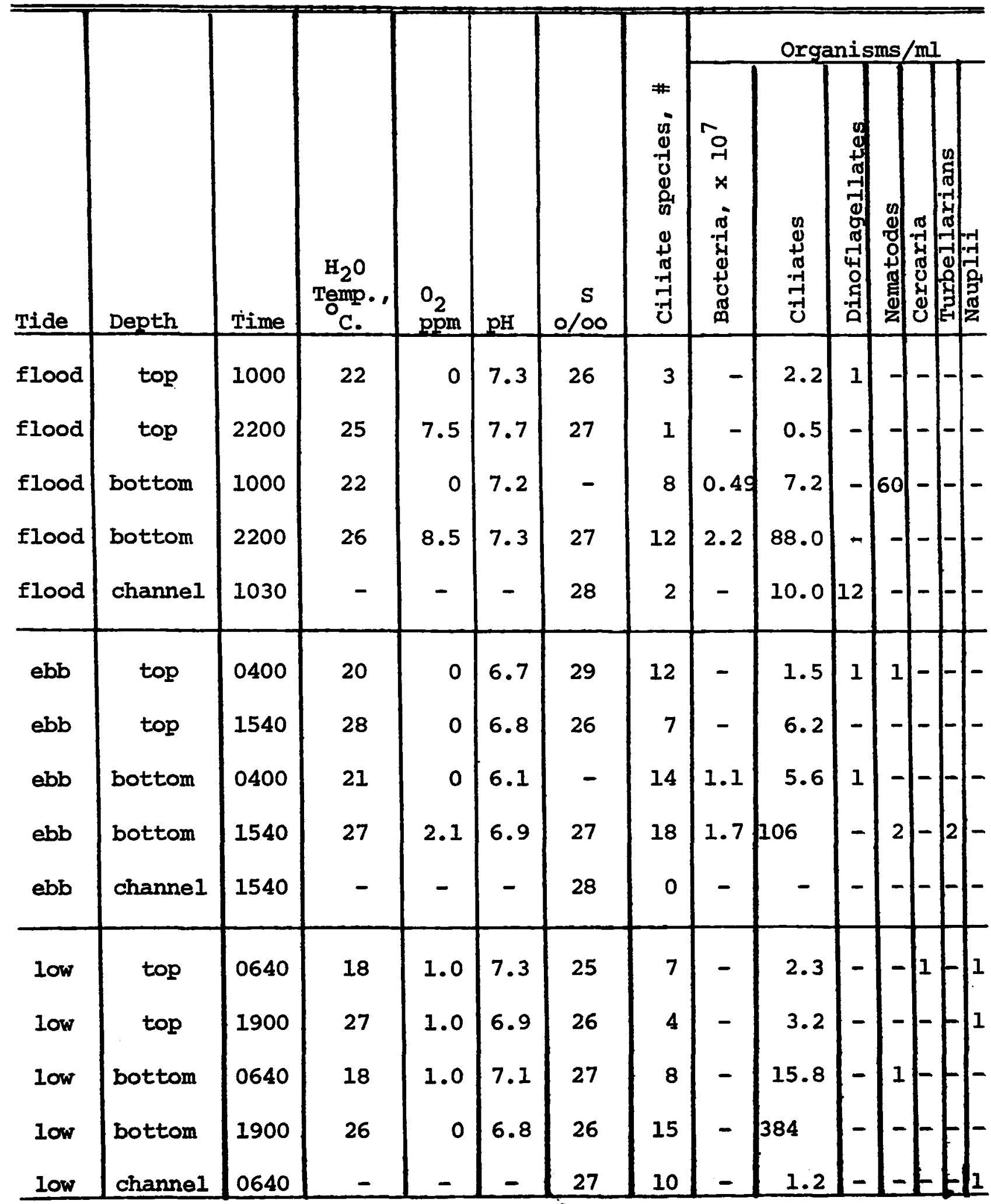


There was no significant correlation between numbers of ciliates and bacterial concentration.

Effects of a Neap Tide - We collected a series of samples every three hours during 29 July 1971 in a manner similar to that described for the above series. They were designed to determine the effect of neap tidal cycles upon relative abundance of ciliates, dinoflagellates, micrometazoa, and bacteria in a lower marsh tidal channel on the ebb and on the flood. At each sampling time, we collected a sample from the water surface and from the water-substratum interface at the station on the lower marsh indicated by a black rectangle in Fig. 2, and simultaneously from a station $90 \mathrm{~m} \mathrm{SW}$ from that station, at a point just beyond the extent of the Spartina peat. As before, no collections were made at high water, since at that time water extends beyond the top of the tidal channel, completely inundating the sampling platform. Physical and biological data are summarized in Table 13.

Physical and Chemical Factors $-\mathrm{O}_{2}$ was uniformly nearly absent. Salinity was nearly constant, at 28 parts per thousand. There was little vertical difference, and little understandable diurnal difference in $\mathrm{pH}$. Water temperature was uniformly much lower in the forenoon, particularly at the time of the morning flood tide.

Biological Factors - Ciliates were present in greater variety (5-8 species) at the bottom than at the surface (1-4 species), and at greater concentrations at the bottom on the ebb tide than on the flood tide. As was the case during a springtide cycle, there again were relatively few ciliates at the channel station. There was no significant correlation between ciliate concentration and bacterial concentration. Bacteria were low and constant in numbers, about an order of magnitude lower than levels estimated for samples collected during the full moon spring tide cycles (July 6 data discussed above). Relatively few micrometazoa were observed, either at the water surface or at the substratum-water interface.

Effect of a New Moon Spring Tide - We collected a series of samples every 3 hrs during a 24-hr period on August 17 and 18, 1971, to determine the effects of new moon spring tidal cycles on the ebb and flow of ciliates, bacteria, dinoflagellates, and micrometazoa in the tidal marsh ditch described above. Since analysis of samples from the water surface in the previous two experiments indicated low and insignificant populations of ciliates and micrometazoa, we sampled only the substratum interface in this series. As before, we also sampled at the substratum surface at a point $90 \mathrm{~m} \mathrm{SW}$ of the lower marsh station. Physical and biological data are summarized in Table 14. 
TABLE 13. PHYSICAL AND BIOLOGICAL PARAMETERS IN THE IOWER MARSH DURING A TIDE. Effect of a neap tide cycle upon physical factors, bacterial concentration, ciliates, and micrometazoa.

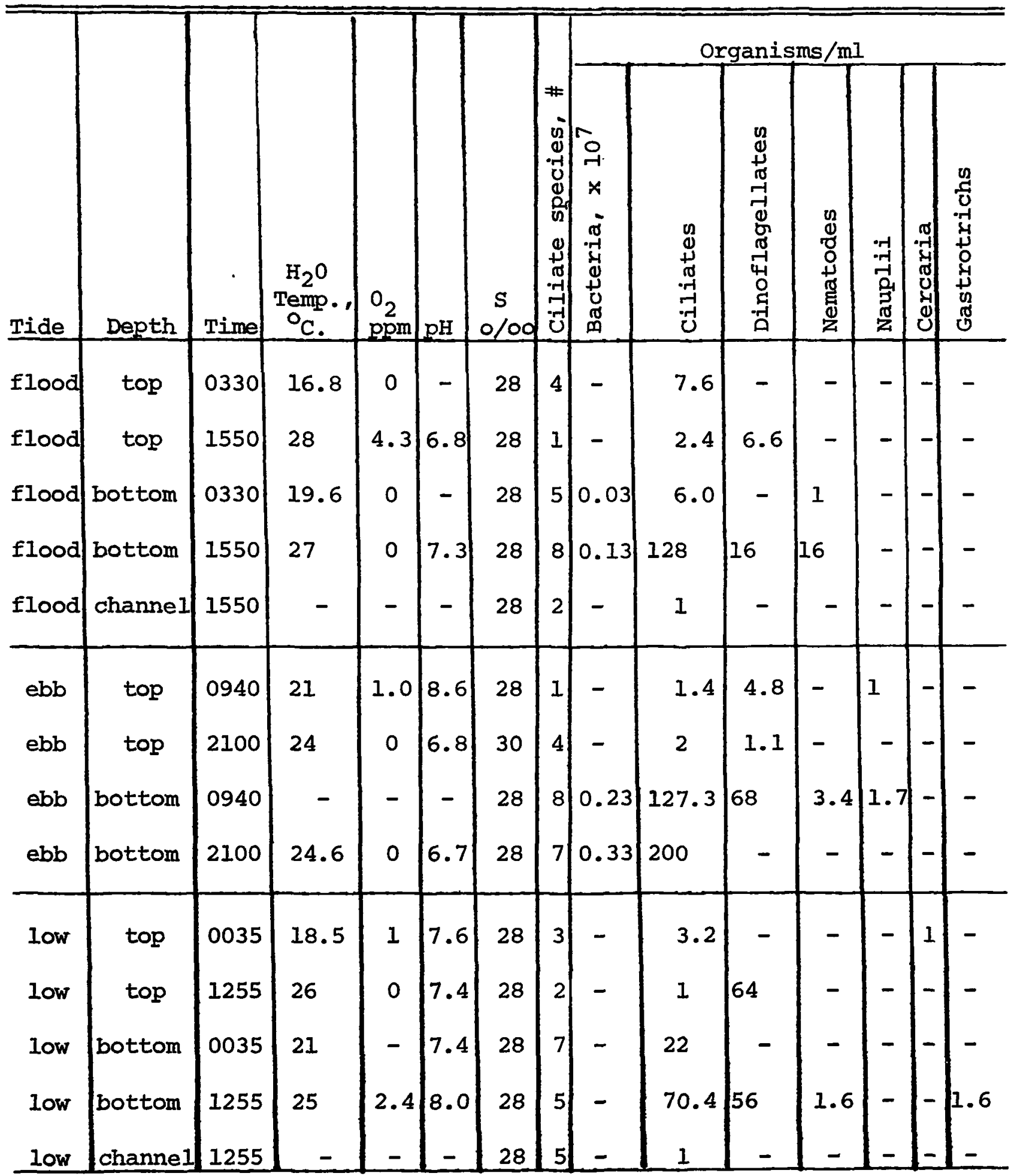


TABLE 14. PHYSICAL AND BIOLOGICAL PARAMETERS, LOWER MARSH, DURING A TIDE.

Effect of a new moon spring tide cycle upon physical factors, bacterial concentration, ciliates, and micrometazoa. Samples taken from bottom.

\begin{tabular}{|c|c|c|c|c|c|c|c|c|c|c|c|c|c|}
\hline & & & & & & \# & \multicolumn{7}{|c|}{ Organisms/ml } \\
\hline Tide & Time & $\begin{array}{c}\mathrm{H}_{2} \mathrm{O} \\
\text { Temp. , } \\
{ }^{\circ}{ }_{\mathrm{C}} \text {. } \\
\end{array}$ & $\begin{array}{l}\mathrm{O}_{2}{ }^{\prime} \\
\text { ppm }\end{array}$ & pH & $\begin{array}{c}S, \\
0 / 00 \\
\end{array}$ & 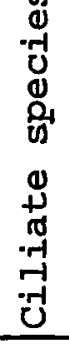 & 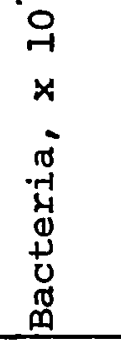 & 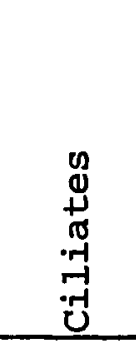 & 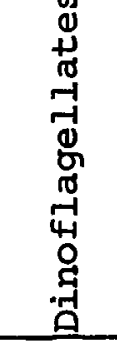 & 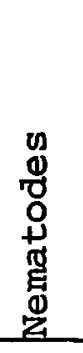 & 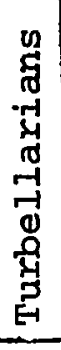 & $\begin{array}{l}02 \\
08 \\
0 \\
0 \\
0 \\
0 \\
0 \\
0 \\
\end{array}$ & 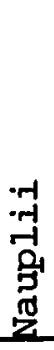 \\
\hline flood & 0930 & - & - & - & 28.5 & 3 & 0.49 & 73.8 & 50 & 1 & - & - & - \\
\hline flood & 2040 & 22 & 0.5 & 6.2 & 28.5 & 6 & 0.03 & 43.2 & - & - & 1 & - & - \\
\hline channel & 0930 & - & - & - & 30 & 1 & - & 0.4 & - & - & -- & - & - \\
\hline$a b b$ & 0330 & 20 & 0 & 6.3 & 29.5 & 7 & 0.79 & 81.7 & - & - & - & 1.7 & - \\
\hline$e b b$ & 1430 & 26 & 3.0 & 6.1 & 29.5 & 10 & 0.17 & 152 & - & - & - & - & - \\
\hline Low & 0630 & 18.5 & 1.1 & 6.5 & 28 & 7 & - & 58.7 & - & 3.6 & - & - & - \\
\hline low & 1740 & 24 & 0 & 6.1 & 29 & 11 & - & 207 & 1.8 & 1.8 & - & - & - \\
\hline channel & 0630 & $=$ & 2.1 & 6.5 & 29.5 & 6 & - & 4.4 & $=$ & 1 & - & - & 1 \\
\hline
\end{tabular}


Physical and Chemical Factors $-\mathrm{O}_{2}$ conc. was uniformly low, as in the previous series. Again salinity was constant at 28.5 - 30 parts per thousand. Hydrogen ion conc. was relatively stable $(6.1-6.5)$.

Water temperature fluctuated considerably during the day rising from an early morning $10 \mathrm{w}$ of $18.5^{\circ} \mathrm{C}$ at $6: 30 \mathrm{a} . \mathrm{m}$. to a high of $26^{\circ} \mathrm{C}$ at $2: 30 \mathrm{p} . \mathrm{m}$., and then gradually decreasing during the evening.

Biological Factors - Ciliates were present in greater variety and in greater concentrations at ebb tide and at low tide than when the channel was subjected to an inflooding of water from the estuary. Estimates of bacterial abundance from samples collected from this series indicate slightly higher concentrations on the ebb tide than on the flood tide, but relatively little correlation between ciliate concentration and bacterial concentration. As before, there were relatively few micromatazoa, in relatively low numbers. 
SECTION IV

DISCUSSION

Because of preliminary indications from previous work that closely related and morphologically similar species may differ significantly in microdistribution 27 a particularly careful and extensive assessment had to be made of the taxonomic position of ciliates encountered. To establish a firm basis for discussion of both autecological and synecological roles of the tidal marsh ciliates, extensive research was conducted under this grant on the ciliate taxonomy 54 to the extent of the necessity of major revision of one order 5 . With this background of understanding, it was then possible to describe, in more detail than is possible here, the anatomy, behavior, autecology, and systematic position of many of the tidal marsh ciliates encountered in this study, including 29 species of relatively poorly known forms, including 4 new species 51 . Thus these data may serve as a baseline for judging protozoan diversity and community structure in marine habitats of differing water quality.

Where ciliate genera are represented in the tidal marsh by several species there were often differences in their relationship to physical and chemical factors. These are most notable within the genus Strombidium. Such a phenomenon is to be expected, and parallels previously published data in intrageneric differences in saprobial valance among genera of fresh water ciliates 56 . Whether or not these situations are interpreted as examples of competitive exclusion, they corrobrate previously published conclusions 27 and further justify careful identification procedures used in ecological studies of protozoa.

The ciliate fauna displays a wide array of locomotory types, sensitivity to various chemical and physical factors, and morphological adaptations. With the exception of a very few species known heretofore primarily only from fresh water (e.g. Colpoda cucullus, Ophryoglena flava, and Spriostomum sp.), the tidal marsh ciliate fauna is essentially a marine assemblage. In general, the locomotory types represented by the species unique to either the upper marsh or the lower marsh (Table 9) were similar; that is, both microhabitats supported a similar number of thigmotactic and planktonic species, while supporting as well a large number of forms of intermediate locomotory type.

Table 10 indicates that of the 10 most regularly encountered species in the upper and lower marsh, only two (Coleps tesselatus and Uronema filificum) showed statistically significant differences in microdistribution. Coleps tesselatus occurred more frequently than expected in the upper marsh while Uronema filificum occurred more frequently in samples from the lower marsh. It is possible that the unusual capacity of U. filificum, to become temporarily sessile by means of temporary attachment 
to the substratum by excretions of its mucocysts may allow members of the species to maintain their position in that habitat and avoid being swept away by tidal currents. Coleps tesselatus on the other hand congregates along substrata to feed upon bacteria attached to the substratum and are thus perhaps more likely to occur in the quieter pools of the upper marsh. The remaining species in Table 10 are either strongly thigmotactic (e.g. Trachelonema oligostriata) or are free-swimming, feeding independent of the substratum (e.g. S. sulcatum). Judging from the similar number of species recorded in each habitat and the similarity of the percent of endemism in the two areas, the diversities of ciliates in the upper and lower marsh appear similar. In general these points are supported by data collected in both the summer of 1970 and the summer of 1971.

Despite elaborate experimental design to allow correlation of ciliate and bacterial concentrations in a patens-panne pond during a period of flushing by a spring tide cycle, little obvious relation was evident. Although there was an increase in diversity of ciliates along the bottom following the flushing of the pond there appeared to be no obvious link with bacterial concentration. In retrospect, it seems likely that bacterial standing crop is such a dynamic phenomenon that one would be required to sample the population more frequently - if not continuously to be able to document the actual relationships of the change of the water mass of the pool following flushing, changes in bacterial populations, and changes in ciliate populations. Although direct microscopic methods for enumeration of bacteria were considered to have sufficient complications that they were not employed in this study, it may be that their advantage in revealing a more exact count of bacteria in a sample might render them useful in future research in this area. Although the Most Probable Number method employed here would allow gross comparisons with other work, direct observation counts may be necessary to evaluate such dynamic changes as may occur during a tidal change.

A number of generalities emerge from measurement of physical and biological parameters in the lower marsh during a full moon spring tide, a neap tide, and a new moon spring tide (Tables 12-14). In general, ciliates were present in greater variety and in larger numbers at ebb tide and low tide than when the channel was subjected to an inflooding of water from the estuary, regardless of the tidal amplitude.

Ciliate populations high in the water colum or near the water surface in the tidal channel in the lower marsh generally either were absent or at relatively low concentrations. However, greater numbers and variety were evident during flood tide than during ebb or low tide. Diversity was higher during a spring tide cycle than during a neap tide cycle.

Of all the ciliates occurring in both the upper and lower marsh, only Coleps tesselatus appeared to occur at a statistically significant higher 
level in the upper marsh and therefore might be looked upon as an upper marsh form. Counts made in the lower marsh across tidal cycles further corroborate this point. The overall frequency of $\mathrm{C}$. tesselatus in the collections summarized in Tables I2-14 was very close to the total percent from all combined lower marsh stations (about 25\%). Yet the percentage seen at low tide $(38.5 \%)$ is higher, and the percentage at ebb (20\%) and flood $(15.4 \%)$ is lower than expected. It is possible that at spring high tide, $C$. tesselatus is flushed from the panne pools down through the channels of the lower marsh and then lost to the estuary with relatively little recruitment to the marsh during the subsequent flooding.

Concomitant sampling from surface mud at the lower edge of the tidal marsh below the channel station consistently showed fewer species of ciliates than the tidal channel station, and sometimes none at all. This finding, along with vertical differences in concentration of ciliates mentioned above, make it appear plausible that ciliates flushed by tidal currents from the upper parts of the marsh settle out on detritus at the bottom of channels rather than remaining higher in the water column and being swept from the marsh in the plankton. Thus it appears most likely that tidal marsh ciliates enter estuarine food webs beyond the marsh by their association with particulate detritus, as has been postulated previously 57 . Ciliates observed high in the water column in tidal channels during flood tide generally represent planktonic forms (e.g. Strobilidium sp., and tintinnids) not ordinarily found in association with substrata higher in the marsh. Ciliate numbers in surface samples in tidal channels during a tide were generally higher during flood tide than during ebb tide reflecting the likely settling out of marsh ciliates during the ebb and an influx of planktonic ciliates from the estuary during flood tide.

Although any attempt to quantify field populations of microorganisms is likely to be fraught with difficulty, and often involves tedious methods, the vertical filter series and subsequent counting method was a practical approach, and yielded consistent results. Unlike other methods for sampling ciliates of marine habitats 58,59 the method is suitable for habitats with considerable organic matter, and avoids loss of relatively thigmotactic forms. Corroboration of direct counts of living ciliates by rapid staining methods such as the nigrosin-mercuric chloride-formalin method allows the necessary viewing of cytoplasmic detail and permanent record to document identification. 
SECTION VII

REFERENCES

1. Lauff, G. H. (ed.). Estuaries. Washington D. C., AAUP, 1967. $757 \mathrm{p}$.

2. Nixon, S. W. and C. A. Oviatt. Ecology of a New England salt marsh. Ecol. Monogr. 43:463-498, 1973 .

3. Redfield, A. C. Development of a New England salt marsh. Ecol. Monogr. 42:201-237, 1972 .

4. Blum, J. L. Nutrient changes in water flooding the high salt marsh. Hyarobiol. 34 (1):95-99, 1969.

5. Burkholder, P. R. Studies on the nutritive value of Spartina grass growing in the marsh areas of coastal Georgia. Bull. Torrey Botan. Club $83(4): 327-334,1956$.

6. Burkholder, P. R. and G. H. Bornside. Decomposition of marsh grass by aerobic marine bacteria. Bull. Torrey Botan. Club 84(5):366383, 1957.

7. Lackey, J. B. The microbiota of estuaries and their roles. In: Estuaries, Lauff, G. H. (ed.). Washington D. C., AAUP, 1967. p. 291-302.

8. McIntyre, A. D. Ecology of marine meiobenthos. Biol. Rev. $44(2)$ : 245-290, 1969.

9. Odum, E. P. and A. A. de la Cruz. Particulate organic detritus in a Georgia salt marsh-estuarine ecosystem. In: Estuaries, Lauff, G. H. (ed.) . Washington D. C., AAUP, 1967. p. 383-388.

10. Blum, J. L. Salt marsh spartinas and associated algae. Ecol. Monogr. $38(3): 199-221,1968$.

11. Pomeroy, L. R. Algal productivity in salt marshes of Georgia. Limnol. Oceanogr. $\underline{4}(4): 387-397,1959$.

12. Teal, J. M. 1962. Energy flow in the salt marsh ecosystem of Georgia. Ecol. 43:614-624, 1962. 
13. Dragesco, J. Les ciliés mésopsammiques littoraux (Systématique, morphologie, écologie. [The mesopsammic littoral ciliates (systematics, morphology, ecology J Trav. Sta. biol. Roscoff 12: 1-356, 1960 .

14. Brown, P. J. Interstitial marsh ciliates. J. Protozool. $\underline{20}(4): 496,1973$.

15. Webb, M. G. An ecological study of brackish water ciliates. J. An. Ecol. 25:148-175, 1956.

16. Bick, H. Autökologische und saprobiologische Untersuchungen an süsswasserciliaten. (Autecological and saprobiological studies on freshwater ciliates.] Hydrobiol. $31(1): 17-36,1968$.

17. Bick, H. The potentialities of ciliated protozoa in the biological assessment of water pollution levels. Int. Symp. on Identification and Measurement of Env. Pollutants. Ottawa, Canada. p. 305-309, 1971.

18. Bick, H. Population dynamics of protozoa associated with the decay of organic materials in fresh water. Amer. Zool. 13:149-160, 1973.

19. Grolière, C. A. and Njine, T. Étude comparée de la dynamique des populations de ciliés dans differents biotopes d'une mare de forêt pendent une année. [Comparative study of the dynamics of populations of ciliates in different biotopes of a forest pond during a year.] Protistol. $\underline{9}(1): 5-16,1973$.

20. Small, E. B. A study of ciliate protozoa from a small polluted stream in east-central Illinois. Amer. Zool. 13:225-230, 1973.

21. Borror, A. C. Morphology and ecology of the benthic ciliated protozoa of Alligator Harbor, Florida. Arch. Protistenk. 106:465534, 1963.

22. Borror, A. C. Ciliate protozoa of the Gulf of Mexico. Bull. Mar. Sci. Gulf Caribbean 12(3):333-349, September 1962.

23. Borror, A. C. Feeding apparatus of the ciliate Cohnilembus verminus (Müllex). ASB Bull. $8(2): 21,1961$.

24. Borror, A. C. Euplotes minuta (Ciliophora, Hypotrichida).

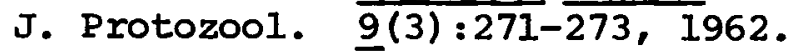

25. Borror, A. C. Distribution of ciliated Protozoa of the genus Diophrys on the New Hampshire coast. Bull. Northern New England Acad. Sci. p. 6-7, October 1963. 
26. Borror, A. C. New and little-known tidal marsh ciliates. Trans. Amer. Microscop. Soc. 84:550-565, 1965.

27. Borror, A. C. Ecology of interstitial ciliates. Trans. Amer. Microscop. Soc. 87:233-243, 1968.

28. Fenchel, T. The ecology of marine microbenthos $I$. The quantitative importance of ciliates as compared with metazoans in various types of sediments. Ophelia 4 :121-137, 1967.

29. Fenchel, T. The ecology of marine microbenthos II. The food of marine benthic ciliates. Ophelia 5:73-121, 1968.

30. Fenchel, T. The ecology of marine microbenthos III. The reproductive potentiąl of ciliates. Ophelia $\underline{5}: 123-136,1968$.

31. Fenchel, T. The ecology of marine microbenthos IV. Structure and function of the benthic ecosystem, its chemical and physical factors and the microfauna communities with special reference to the ciliated protozoa. Ophelia 6:1-182, July 1969.

32. Johannes, R. E. Influence of marine protozoa on nutrient regeneration. Limol. Oceanogr. 10(3):434-442, 1965.

33. Spoon, D. M., K. A. Krieger, and W. D. Burbank. Quantitative studies of the interactions between metazoans and protozoans of fresh and salt water aufwuchs communities. III Intern. Congr. Protozool. p. 34-35, July 1969.

34. Ax, P. and R. Ax. Experimentelle Untersuchungen "uber die Salzgehalstoleranz von Ciliaten aus dem Brackwasser und süsswasser. [Experimental investigation of salinity tolerance of ciliates from brackish and fresh water] Biol. Zbl. 79:7-31, 1960.

35. Corliss, J. O. Protozoan ecology: a note on its current status. Amer. Zool. 13:145-148, 1973.

36. Fauré-Fremiet, E. Chemical aspects of ecology. In: Chemical Zoology, Vol. I(Protozoa). Kidder, G. W. (ed.). New York, Academic Press, 1967. p. 21-54.

37. Hairston, N. G., J. D. Allan, R. K. Colwell, D. J. Futuyma, J. Howel1, M. D. Lubin, J. Mathias, and J. H. Vandermeer. The relationship between species diversity and stability: an experimental approach with protozoa and bacteria. Ecology 49:1091-1101, 1968. 
38. Noland, L. E. and M. Gojdics. Ecology of free-living protozoa. In: Research in Protozoology, Vol. II, Chen, T. T. (ed.). London, Pergamon Press, 1967. p. 215-266.

39. Jackson, C. F. A biological survey of Great Bay. 1. Physical and biological features of Great Bay and the present status of its marine resources. Marine Fish. Comm., 1944. P. 1-61.

40. Metcalf, T. G. and W. C. Stiles. The accumulation of enteric viruses by the oyster, Crassostrea virginica. J. Infect. Diseases $115: 68-76,1965$.

41. Slanetz, L. W. and C. H. Bartley. Coliforms, fecal streptococci and Salmonella in seawater and shellfish. Health Lab. Sci. 5:66-78, 1968.

42. Biernacka, I. Die Protozoenfauna in der Danziger Bucht I. Die Protozoen in einigen Biotopen der seeküste. [The protozoan fauna in Danzig Bay I. The protozoa in some biotopes of the seacoast.J Polsk. Arch. Hydrobiol. 10(23):39-109, 1962.

43. Czapik, A. Mikrofauna slonawego jeziora Ptasi Raj. (Microfauna of brackish lake Ptasi Raj.] Polsk. Arch. Hydrobiol. 10(23):371-378, 1962.

44. Dietz, G. Beitrag zur Kenntnis der Ciliatenfauna einiger Brackwassertumpel (etangs) der Franzősischen Mittelmeerküte. [Contribution to the knowledge of the ciliate fauna of some brackish ponds of the French Mediterranian coast.] vie et Milieu 15:47-93, 1964.

45. Lackey, J. B. Bottom sampling and environmental niches. Limnol. Oceanogr. $\underline{6}(3): 271-279,1961$.

46. Reuter, J. Einige faunistische und ökologische Beobachtungen über Felsentumpel-ziliaten. [Some faunistic and ecological observations on rockpool ciliates] Acta Zool. Fennica 99:1-42, 1961.

47. Burke, J. D. Determination of oxygen in water using a 10-ml. syringe. J. Mitchell Soc. p. 145-147, November 1962.

48. Borror, A. C. Nigrosin-HgCl $2-$ Formalin; a stain-fixative for ciliates (Protozoa, Ciliophora). Stain Technol. 43(5):293-294, 1968.

49. Borror, A. C. Application of the stain-fixative nigrosin- $\mathrm{HgCl}_{2}-$ formalin to fragile or contractile ciliates. Trans. Amer.

Microscop. Soc. 88(3):454-458, 1969. 
50. Corliss, J. 0. Silver impregnation of ciliated protozoa by the Chatton-Lwoff technic. Stain Technol. 28:97-100, 1953.

51. Borror, A. C. Tidal marsh ciliates (Protozoa): morphology, ecology, systematics. Acta Protozool. 10(2):29-71, 1972.

52. Porter, J. R. Bacterial chemistry and physiology. New York, John Wiley and Sons, Inc., 1946. $1073 \mathrm{p}$.

53. Jannasch, H. W. and G. E. Jones. Bacterial populations in seawater as determined by different methods of enumeration. Limnol. Oceanogr. 4 (1):128-139, 159 .

54. Borror, A. C. Marine flora and fauna of the northeastern United States. Protozoa: Ciliophora. NOAA Tech. Rept. NMFS Circ-378, September 1973. 62 p.

55. Borror, A. C. Revision of the order Hypotrichida (Ciliophora, Protozoa). J. Protozool. 19(1):1-23, 1972.

56. Bick, H. and S. Kunze. Eine Zusammenstellung von aut8kologischen und saprobiologischen Befunden an slsswasserciliaten. [A review of autecological and saprobiological data on freshwater ciliates.] Int. Rev. ges. Hydrobiol. 56(3):337-384, 1971.

57. Fenchel, T. Studies on the decomposition of organic detritus derived from the turtle grass Thalassia testudinum. Limnol. Oceanogr. 15(1):14-20, 1970 .

58. Fjeld, P. On some psammobiotic ciliates from Drфbak (Norway). Nytt Mag. Zool. 3:5-65, 1955.

59. Uhlig, G. Untersuchungen zur Extraktion der vagilen Mikrofauna aus marinen Sedimenten. [Investigation on extraction of vagile microfauna from marine sediments.] Verh. Deutsch. Zool. Ges. 10:151-157, 1965. 
SECTION VIII

LIST OF PUBLICATIONS

Borror, A. C. Revision of the order Hypotrichida (Ciliophora, Protozoa). J. Protozool. 19(1):1-23, 1972 .

Borror, A. C. Tidal marsh ciliates (Protozoa) : morphology, ecology, systematics. Acta Protozool. 10(2):29-71, 1972 .

Borror, A. C. Marine flora and fauna of the northeastern United States: Protozoa: Ciliophora. NOAA Tech. Report NMFS Circ-378, 62 pp. 1973. 
SELECTED WATER

RESOURCES ABSTRACTS

INPUT TRANSACTION FORM

4. Title

Environmental requirements of selected estuarine cillated protozoa.

7. Author(s).

Arthur C. Borror

9. Organization

Department of Zoology and the Jackson Estuarine Lab.

University of New Hampshire

Durham, New Hampshire

03824

3. Accession No.

5. Report Date

6.

8. Performiag Organization REx $-66012-74-031$

10. Project No. 18080 FBW

11. Contract/Grant No.

13. Type of Report and Period Covered

12. Sponsoring Organization Environinental Protection Agency, Office of Res, \& Monitoring

15. Supplementary Notes

16. Abstract Measurements of temperature, $\mathrm{pH}$, oxygen concentration, $\mathrm{H}_{2} \mathrm{~S}$ concentration, salinity, bacterial concentration, occurrence of micrometazoa, and distribution and abundance of clliated protozoa were recorded during the summers of 1970 and 1971 in a. tidal marsh at Adams Pt., Durham, New Hampshire.

Numerous differences in ciliate distribution occurred between the upper (Spartina patens) marsh and the lower (Spartina alterniflora) marsh. Physical and biological parameters of a patens-panne pond were measured during a 2-week period involving the Initial flushing of the pool by a session of full moon spring tides. Effects of a full moon spring tide cycle, a neap tide cycle, and a new moon ppring tide cycle for one station in the lower marsh were evaluated.

During 1970 and 1971, 103 species of cillates, representing 41 families and 10 orders were identified, including 4 new species. Several instances of correlations between cillate abundance and oxygen concentration, $\mathrm{H}_{2} \mathrm{~S}$ concentration, and-salinity were observed.

Contribution of tidal marsh ciliates in general to estuarine food webs probably occurs through their association with particulate detritus.

This report was submitted in fulfillment of Project Iumber 18080 FBW by Arthur C. Borror under the sponsorship of the Environmental Protection Agency. Work was completed as of September, 1971.

17a. Descriptors

estuarine, ciliate, protozoa, tidal marsh, distribution, ecology

17b. Identifiers

17c. COWRR Field \& Group

\begin{tabular}{|c|c|c|c|}
\hline 18. Availability & $\begin{array}{l}\text { 19. Security Class. } \\
\text { (Report) } \\
\text { 30. Securiky class. } \\
\text { (Poge) }\end{array}$ & $\begin{array}{l}\text { 21. Wo, of } \\
\text { 2ages } \\
\text { 22. Price }\end{array}$ & $\begin{array}{l}\text { Send TO: } \\
\text { WATER RESOURCES SCIENTIFIC INFORMATION CENTER } \\
\text { U.S. DEPARTMENT OF THE INTERIOR } \\
\text { WASHINGTON. D. C. } 20240\end{array}$ \\
\hline Abstractor & & tion & \\
\hline
\end{tabular}

